\title{
3-Substituted 1-Naphthamidomethyl-C-galactosyls Interact with Two Unique Sub-Sites for High-Affinity and High-Selectivity Inhibition of Galectin-3
}

\author{
Alexander Dahlqvist ${ }^{1,+}$, Santanu Mandal ${ }^{1,+}{ }^{+}$, Kristoffer Peterson $^{1} \mathbb{D}$, Maria Håkansson ${ }^{2}$, \\ Derek T. Logan ${ }^{2,3}$, Fredrik R. Zetterberg ${ }^{4}\left(\mathbb{D}\right.$, , Hakon Leffler ${ }^{5}$ (D) and Ulf J. Nilsson ${ }^{1, *(D)}$ \\ 1 Centre for Analysis and Synthesis, Department of Chemistry, Lund University, POB124, \\ SE-22100 Lund, Sweden; alexander.dahlqvist@chem.lu.se (A.D.); santanuiiser@gmail.com (S.M.); \\ kristoffer.peterson@redglead.com (K.P.) \\ 2 SARomics Biostructures AB, Medicon Village, SE-223 63 Lund, Sweden; \\ maria.hakansson@saromics.com (M.H.); derek.logan@biochemistry.lu.se (D.T.L.) \\ 3 Biochemistry and Structural Biology, Center for Molecular Protein Science, Department of Chemistry, \\ Lund University, POB124, SE-22100 Lund, Sweden \\ 4 Galecto Biotech AB, Sahlgrenska Science Park, Medicinaregatan 8 A, SE-413 46 Gothenburg, Sweden; \\ FZ@Galecto.com \\ 5 Department of Laboratory Medicine, Section MIG, Lund University BMC-C1228b, Klinikgatan 28, \\ 22184 Lund, Sweden; hakon.leffler@med.lu.se \\ * Correspondence: ulf.nilsson@chem.lu.se \\ + These authors contributed equally and share first authorship.
}

Received: 5 November 2019; Accepted: 11 December 2019; Published: 12 December 2019

\begin{abstract}
The galectins are a family of galactose-binding proteins playing key roles in inflammatory processes and cancer. However, they are structurally very closely related, and discovery of highly selective inhibitors is challenging. In this work, we report the design of novel inhibitors binding to a subsite unique to galectin-3, which confers both high selectivity and affinity towards galectin-3. Olefin cross metathesis between allyl $\beta$-C-galactopyranosyl and 1-vinylnaphthalenes or acylation of aminomethyl $\beta$-C-galactopyranosyl with 1-naphthoic acid derivatives gave $C$-galactopyranosyls carrying 1-naphthamide structural elements that interacted favorably with a galectin-3 unique subsite according to molecular modeling and X-ray structural analysis of two inhibitor-galectin-3 complexes. Affinities were down to sub- $\mu \mathrm{M}$ and selectivities over galectin-1, 2, $4 \mathrm{~N}$-terminal domain, $4 \mathrm{C}$-terminal domain, 7, $8 \mathrm{~N}$-terminal domain, $9 \mathrm{~N}$-terminal domain, and $9 \mathrm{C}$-terminal domain were high. These results show that high affinity and selectivity for a single galectin can be achieved by targeting unique subsites, which holds promise for further development of small and selective galectin inhibitors.
\end{abstract}

Keywords: galectin-3; inhibitor; selectivity; C-galactosyl; naphthamide

\section{Introduction}

Efforts towards the discovery of selective and drug-like inhibitors of the galectin family of proteins have escalated during the last decade as a consequence of an increasing awareness of the important roles of galectins in e.g., cell adhesion, tumor growth and metastasis, inflammation, and immune regulation [1,2]. Galectins may dimerize (e.g., galectin-1,2, and 7), oligomerize (galectin-3), or have two ligand-binding sites within one polypeptide sequence (galectins-4, 6, 8, 9, and 12). These structural features enable crosslinking of endogenous glycoconjugates (e.g., glycoproteins) via oligosaccharides that carry the key ligand monosaccharide galactose [3-5]. Such cross-linking may in turn influence for example glycoprotein localization (on cell membrane or in intracellular vesicles) 
and cellular trafficking, which may influence glycoprotein function [6]. Endogenous oligosaccharide ligands and a majority of synthetic galactose-based inhibitors display at best partial selectivity among the galectins, which is why further development of inhibitors with enhanced selectivity is of significance. O-galactosyl aldoximes [7,8] and C1-galactopyranosyl oxazoles [9] carrying bicyclic aromatic $\mathrm{N}$-substituents (Figure 1A) were earlier reported to be comparatively potent and highly selective galectin-3 inhibitors. A molecular modeling-based explanation was proposed in which the selectivity was due to anomeric aldoxime or oxazole substituents occupying and interacting favorably with a subsite unique to galectin-3 located perpendicular to the core galactoside subsite $C$ conserved within galectins [4], with bicyclic aromatic substituents, such as the 1-naphthyl derivatives $\mathbf{1}$ and $\mathbf{2}$ (Figure 1A), being the most potent ones. Although these O-galactosyl aldoximes (1) and C1-galactosyl oxazoles (2) were selective and had improved affinity for galectin-3 over e.g., galactose, lactose, and $\mathrm{N}$-acetyl-lactosamine, even further enhanced affinity is needed to improve pharmacological properties. Furthermore, the anomeric aldoxime functionality should preferably be replaced with functionalities less prone to undergo equilibrating reactions under physiological conditions, as an oxime ligand that exchanges with for example protein lysine side chains or other amino groups will likely possess altered galectin binding properties. Herein, we report on the synthesis and evaluation of anomeric aromatic amides and trans-alkenes as aldoxime and oxazole bioisosteres (Figure 1), leading to the discovery that amides possess galectin-3 affinities that reach the nanomolar range, while retaining the excellent selectivity earlier demonstrated for the known aldoximes and oxazoles. Furthermore, structural analysis of two anomeric 1-naphthyl amides in complex with galectin-3 confirmed that the naphthyl moiety occupied the site perpendicular to the conserved subsite $\mathrm{C}$, while the amide $\mathrm{N}$ and $\mathrm{O}$ atoms were engaged in a hydrogen bond network with Q182-R186-R162 side chains, a buried water molecule, and the ligand galactose $\mathrm{HO} 2$, which is suggested to explain why the amide proved to be an ideal anomeric functional group over the aldoxime, oxazole, and trans-alkene.
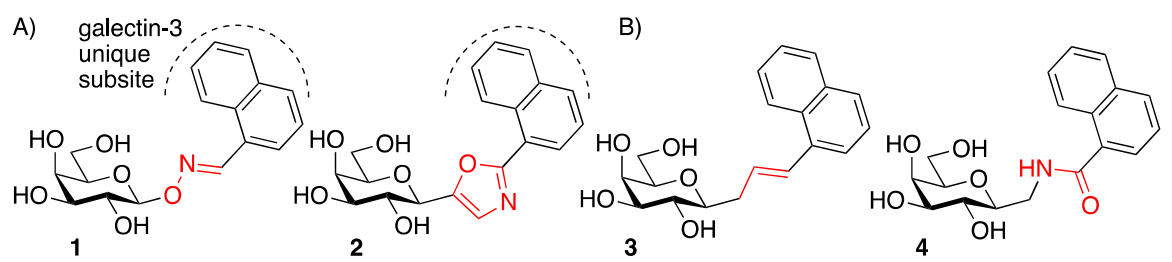

Figure 1. (A) Galectin-3 selective galactosyl aldoxime 1 and oxazole 2. (B) The proposed bioisosteric alkene 3 and amide 4 .

\section{Results and Discussion}

The alkene isostere 3 was synthesized via an olefin metathesis between allyl $\beta$-C-galactopyranosyl 5 [10] and 1-vinylnaphthalene, followed by deacetylation, and the amide 4 was synthesized by acylation of the aminomethyl $\beta$-C-galactopyranosyl 6 [11] (Scheme 1). The yields of the amides 4 and 7-11 were apparently low due to the presence of residual inseparable aluminum salts in C-galactosyl 5 resulting from its synthesis by $\mathrm{LiAlH}_{4}$ reduction of the preceding nitrile, as originally also reported by Coxon and co-workers for similar reactions [11].
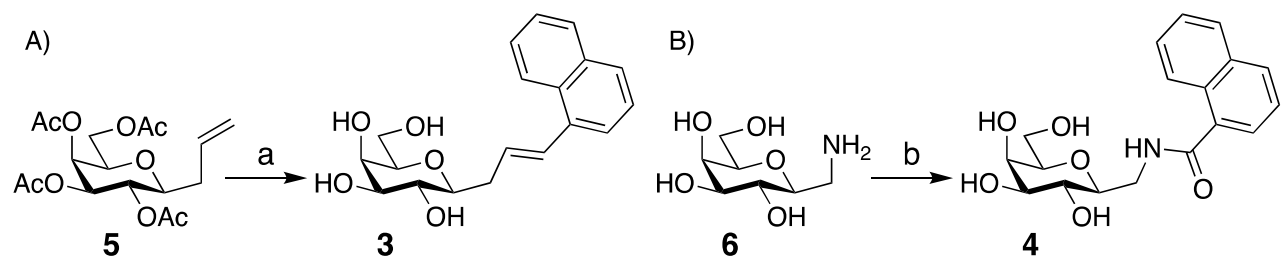

Scheme 1. Synthesis of $\beta$-C-galactopyranosyls (A) alkene 3 and (B) amide 4 . Reagents and conditions: (a) ${ }^{\mathrm{i}}$ 1-vinylnaphthalene, Grubb's catalyst 2 nd generation, $\mathrm{CH}_{2} \mathrm{Cl}_{2}$, reflux, ${ }^{\text {ii }} \mathrm{NaOMe}, \mathrm{MeOH}, 75 \%$ and (b) 1-naphthoyl chloride, $\mathrm{Na}_{2} \mathrm{CO}_{3}, \mathrm{H}_{2} \mathrm{O}, \mathrm{THF}, 68 \%$. 
Evaluation of 3 and 4 as inhibitors of galectin-3 in a competitive fluorescence polarization assay [12,13], revealed that while the alkene 3 was a less efficient inhibitor than the parent aldoxime $\mathbf{1}$ and oxazole $\mathbf{2}$, the amide $\mathbf{4}$ was significantly more potent (Table 1). Inspired by the discovery that amides were superior in binding to galectin-3, we synthesized a series of substituted bicyclic amides 7-11 by acylating 6 with different acyl chlorides following the same procedure as in the synthesis of 4 (Scheme 2). Substituent effects are very minor, as all substituted 1-naphthoyl derivatives 7-11 were all inhibitors in the low $\mu \mathrm{M}$ range (Table 1). The 6-fluoro derivative 8 was significantly weaker, while the 4-fluoro and 4-methoxy derivatives $\mathbf{7}$ and $\mathbf{1 1}$ were somewhat better than the other 1-naphthoyl derivatives.

Table 1. Dissociation constants $\left(\mathrm{K}_{\mathrm{d}}, \mu \mathrm{M}\right)$ of methyl $\beta$-D-galactopyranosyls [14], aldoxime 1, oxazole 2, alkene $\mathbf{3}$, and amides $\mathbf{4}$, and $\mathbf{7 - 1 1}$ against galectin-3 determined in a competitive fluorescence anisotropy assay [12,13].

\begin{tabular}{cccccccccc}
\hline Me $\beta$-gal & $\mathbf{1}$ & $\mathbf{2}$ & $\mathbf{3}$ & $\mathbf{4}$ & $\mathbf{7}$ & $\mathbf{8}$ & $\mathbf{9}$ & $\mathbf{1 0}$ & $\mathbf{1 1}$ \\
\hline 4400 & $370[7,8]$ & $90[9]$ & $1600 \pm 90^{1}$ & $39 \pm 2.3$ & $22 \pm 0.75$ & $79 \pm 7.8$ & $43 \pm 0.38$ & $28 \pm 0.81$ & $22 \pm 0.79$ \\
\hline
\end{tabular}

${ }^{1}$ Dissociation constant averages and SEM were calculated from two to eight single-point measurements showing between $20 \%$ and $80 \%$ inhibition.

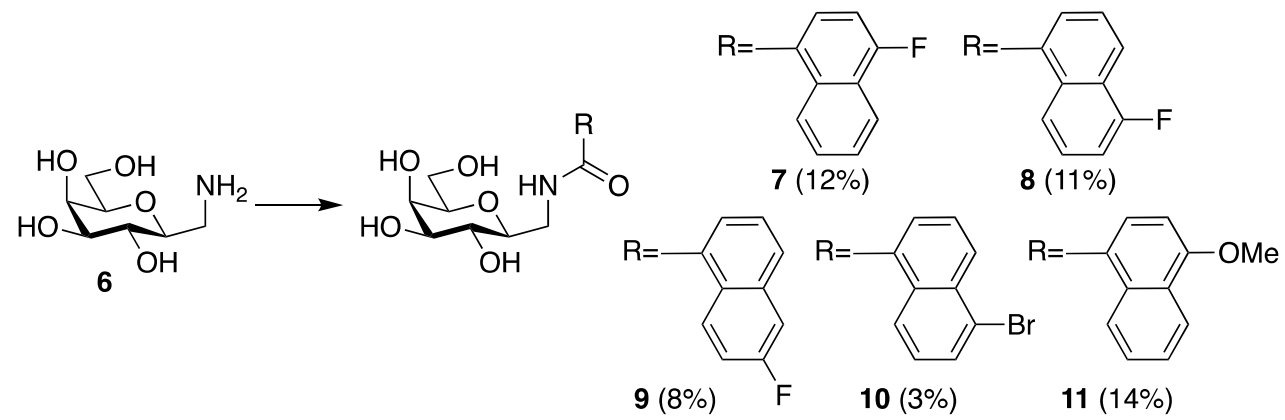

Scheme 2. Synthesis of aromatic amidomethyl $\beta$-C-galactopyranosyls 7-11. Reagents and conditions: Acyl chloride, $\mathrm{Na}_{2} \mathrm{CO}_{3}, \mathrm{H}_{2} \mathrm{O}$, THF.

With the 4-fluoro-1-naphthamide 7 being identified as one of two naphthamide ligands showing the highest affinity, the hypothesis that combining this C1-naphthamido moiety with known affinity-enhancing 5,6-difluorocoumarin- [15,16] and 3,4,5-trifluorophenyltriazolyl moieties [17,18] in the same manner as described for the aldoxime derivatives [8] to give the doubly derivatized C-galactosyls 14 and 19 (Scheme 3) appeared plausible. Stannylidene-mediated propargylation at $\mathrm{HO} 3$ of $\mathbf{7}$ gave the propargyl ether 12. The remaining hydroxyl groups of $\mathbf{1 2}$ were acetylated to give 13 to be used as the alkyne source together with 5,6-difluorosalicylic aldehyde and tosyl azide for $\mathrm{Cu}(\mathrm{I})$-mediated multicomponent coumarin synthesis $[15,19]$ followed by de-acetylation to give the difluoro-coumarin 14.

Access to the triazole group in 19 requires double inversion reactions at $\mathrm{C} 3$ of $\mathbf{7}$ to introduce an azido group for a $\mathrm{Cu}(\mathrm{I})$-catalyzed cycloaddition reaction. Regioselective sulfonylation of 7 installed a bis-3,5-trifluoromethylbenzenethanolsulfonate at $\mathrm{O} 3$ (15), a leaving group recently demonstrated to possess optimal balance between reactivity and stability for inversions at galactose C3 [20]. Inversion of 15 with $\mathrm{CsOAc}$ in $\mathrm{DMSO}$ at $90{ }^{\circ} \mathrm{C}$ for 3 days gave the guloside 16. De-acetylation of 16, regioselective 2-O-acetylation, 3-O-triflation, and treatment with sodium azide gave the 3-azido derivative 18. Acetate and benzylidene removal followed by $\mathrm{Cu}(\mathrm{I})$-catalyzed cycloaddition [21,22] with 3,4,5-trifluorophenylacetylene gave 19 in 42\% yield. Evaluation of 14 and 19 indeed revealed low to sub- $\mu \mathrm{M}$ affinities for galectin-3 (Table 2). While the coumarin 14 bound four-fold weaker to galectin-3 than 19, it displayed a better selectivity over the other galectins evaluated, as 19 also inhibited galectin-4C (C-terminal domain) with low $\mu \mathrm{M}$ affinity. 


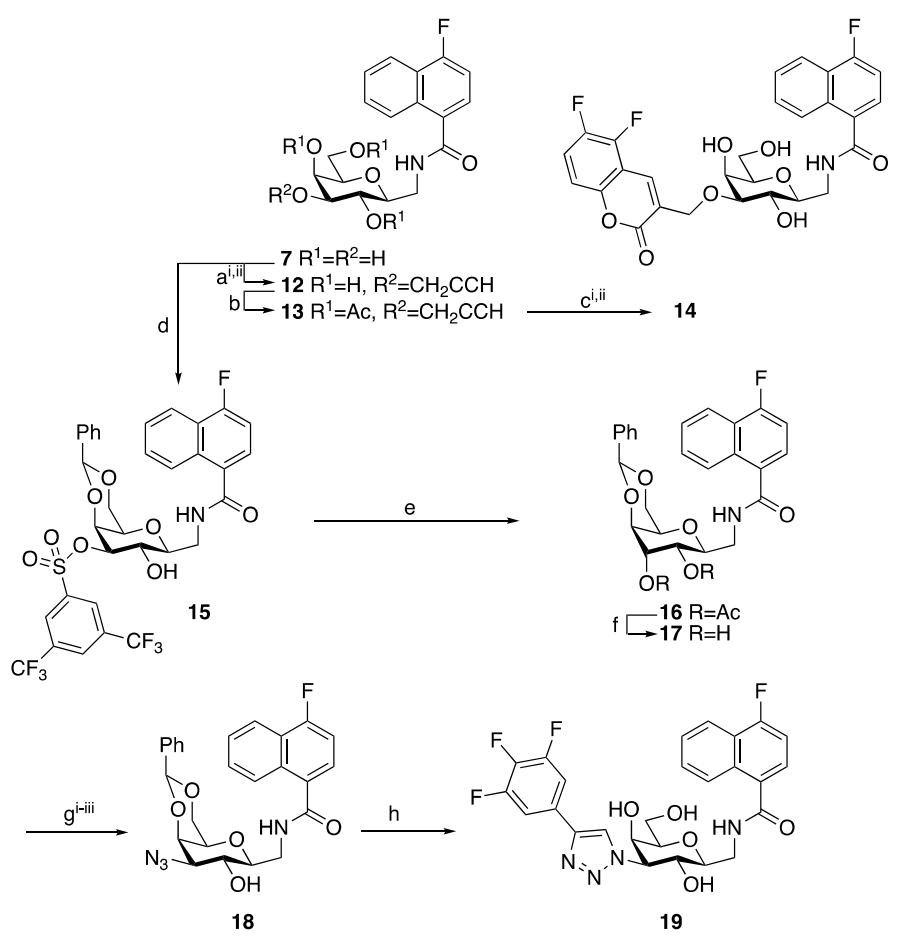

Scheme 3. Synthesis of compounds 14 and 19. Reagents and conditions: (a) ${ }^{\mathrm{i}} \mathrm{Bu}_{2} \mathrm{SnO}, \mathrm{MeOH}$, ii propargyl bromide, 1,4-dioxane (79\%); (b) $\mathrm{Ac}_{2} \mathrm{O}$, pyridine (94\%); (c) ${ }^{\mathrm{i}}$ 5,6-difluorosalicyldehyde, tosyl azide, $\mathrm{Et}_{3} \mathrm{~N}$, CuI, THF. ${ }^{\text {ii }} \mathrm{NaOMe}, \mathrm{MeOH}(40 \%)$; (d) ${ }^{\mathrm{i}}$ benzaldehyde dimethyl acetal, p-toluenesulfonic acid, DMF. ii $\mathrm{Bu}_{2} \mathrm{SnCl}_{2}$, THF, PEMP, 3,5-bis-(trifluoromethyl)benzenesulfonyl chloride (52\%); (e) ${ }^{\mathrm{i}} \mathrm{Ac}_{2} \mathrm{O}$, pyridine, ${ }^{\text {ii }} \mathrm{CsOAc}, \mathrm{DMSO}, 90{ }^{\circ} \mathrm{C}, 3$ days (35\%); (f) $\mathrm{NaOMe}, \mathrm{MeOH}(98 \%)$; (g) ${ }^{\mathrm{i}}$ dry $\mathrm{CH}_{2} \mathrm{Cl}_{2}$, pyridine, acetyl chloride, ${ }^{\text {ii }}$ dry $\mathrm{CH}_{2} \mathrm{Cl}_{2}, \mathrm{Tf}_{2} \mathrm{O}$, ${ }^{\text {iii }} \mathrm{DMSO}, \mathrm{NaN}_{3}, 60^{\circ} \mathrm{C}, 8 \mathrm{~h}(15 \%)$; and (h) ${ }^{\mathrm{i}} 90 \% \mathrm{AcOH}, 90{ }^{\circ} \mathrm{C}, 3 \mathrm{~h}$, ii $\mathrm{NaOMe}, \mathrm{MeOH}$, iii $\mathrm{DMF}, 3,4,5$-trifluorophenyl acetylene, $\mathrm{CuI}, \mathrm{Et}_{3} \mathrm{~N}$, room temperature, 2 days (42\%). Overall yields were $30 \%$ over 3 steps for the synthesis of $\mathbf{1 4}$ and $2 \%$ over 5 steps for the synthesis of 19 from the 4-fluoronaphthamide 7.

Table 2. Dissociation constants $\left(\mathrm{K}_{\mathrm{d}}, \mu \mathrm{M}\right)$ of compounds 14 and 19 against galectin-1, 3, 4N, 4C, 7, 8N, $9 \mathrm{~N}$, and $9 \mathrm{C}$ determined in a competitive fluorescence anisotropy assay.

\begin{tabular}{ccccccccc}
\hline \multicolumn{7}{c}{ Galectin } \\
\hline & $\mathbf{1}$ & $\mathbf{3}$ & $\mathbf{4 N ^ { \mathbf { 1 } }}$ & $\mathbf{4 \mathbf { C } ^ { \mathbf { 2 } }}$ & $\mathbf{7}$ & $\mathbf{8 N}^{\mathbf{1}}$ & $\mathbf{9 N}^{\mathbf{1}}$ & $\mathbf{9 C}^{\mathbf{2}}$ \\
\hline $\mathbf{1 4}$ & $220 \pm 19^{3}$ & $2.0 \pm 0.18$ & $870 \pm 170$ & $100 \pm 43$ & $\mathrm{ND}^{4}$ & $1300 \pm 150$ & $>2000$ & $\mathrm{ND}$ \\
$\mathbf{1 9}$ & $23 \pm 1.4$ & $0.54 \pm 0.060$ & $31 \pm 0.80$ & $1.3 \pm 0.039$ & $>500$ & $1000 \pm 270$ & $14 \pm 0.89$ & $130 \pm 6$ \\
Me $\beta$-gal & $>10,000[14]$ & $4400[14]$ & $6600[23]$ & $10,000[23]$ & $4800[14]$ & $6300[14]$ & $3300[14]$ & $8600[24]$ \\
\hline
\end{tabular}

${ }^{1} \mathrm{~N}$-terminal domain ${ }^{2} \mathrm{C}$-terminal domain. ${ }^{3}$ Dissociation constant averages and SEM were calculated from two to eight single-point measurements showing between $20 \%$ and $80 \%$ inhibition. ${ }^{4}$ Not determined.

In order to understand the structural basis for the affinities and selectivities of compounds $\mathbf{1 4}$ and 19, the structures of their complexes with galectin-3 were determined with X-ray crystallography (Table 3 and Figure 2). Compounds 14 and 19 were soluble at $20 \mathrm{mg} / \mathrm{mL}$, which allowed for co-crystallizations to be performed to generate crystals that diffracted down to 1.5 and $1.4 \AA$ resolution, respectively, with 14 and 19. The good solubility of 14 and 19 in the crystallization buffer is noteworthy as this suggests that both 14 and 19 can be dissolved in buffer at concentrations needed in cell or in vivo experiments involving selective galectin-3 inhibition. Both complexes revealed that the galactose ring of $\mathbf{1 4}$ and $\mathbf{1 9}$ bound the conserved galactose site of galectin-3 [25], which suggests that both 14 and 19 are specific for the glycan binding site (Figure 2). Furthermore, the naphthyl moieties of $\mathbf{1 4}$ and $\mathbf{1 9}$ indeed bound the pocket perpendicularly above the $\beta$-face of the galactoside site, which provides an explanation for the high galectin-3 selectivity of $\mathbf{1 4}$ and $\mathbf{1 9}$ as this pocket is unique to galectin-3. Furthermore, the naphthyl 
rings of 14 and 19 stack on top of and along the R162 side chain methylenes and guanidinium ion, which possibly accounts for some of the affinity enhancements of 14 and 19 via guanidinium- $\pi / \pi-\pi$ and $\mathrm{CH}-\pi$ stacking interactions. The 4-fluoro atom of the naphthyls of $\mathbf{1 4}$ and $\mathbf{1 9}$ does not form any specific interactions with galectin-3, which may explain its marginal effects on affinity (cf. 4 and 7). Given that compounds 4 and 7-11 binds with the same complex geometry as 14 and 19, then any substituent influence on the naphthyl ring electron densities of 7-11 apparently has minor influence on the stacking interaction of the ligand naphthyl with R162 alkyl side chain atoms or guanidinium ion. The trifluorophenyl ring of 19 is placed in between the sidechain or R144 and the S3 $\beta$-strand, which is the same as recently described for thiodisaccharide- and galactose-based ligands $[17,18,26]$. The coumaryl moiety of $\mathbf{1 4}$ is similarly positioned between the R144 side chain and the S3 $\beta$-strand, which is different from that observed for earlier coumaryl-derivatized galactosides in which R144 is aligned along the protein surface and below the coumaryl moiety [15]. This is most probably caused by the interaction of the coumarin fluorine atoms of $\mathbf{1 4}$ forming multipolar $\mathrm{C}-\mathrm{F} \cdots \mathrm{H}-\mathrm{N}, \mathrm{C}-\mathrm{F} \cdots \mathrm{C}=\mathrm{O}$, and C-F...H-C $\alpha$ interactions [27] (Figure 2B). The closest interactions are with the C $\alpha$ of G238 (3.0 $\AA$ ) and with ND2 of N160 (3.2 ̊). In addition, longer fluorine-amide carbonyl interactions with residues R144, I145, and S237 are present (3.6-3.9 A). Fluorine-amide carbonyl interactions have been observed for fluorophenyl-carrying ligands rings binding galectin-3 [17,18,28-30], but the magnitude of such interactions' contribution to free energy of galectin-3 binding has been questioned [26].

Table 3. Data processing and refinement statistics for the X-ray crystal structures. Values in parentheses are for the highest resolution shell, unless noted otherwise. rmsd = root mean square deviation; $R_{\text {merge }}=\frac{\sum_{h k l} \sum_{i}|| \overline{F_{h k l}}|-| F_{h k l, i}||}{\sum_{h k l} \sum_{i}\left|F_{h k l, i}\right|}$, where $\left|\overline{F_{h k l}}\right|$ is the mean of all observations $\left|F_{h k l, i}\right|$ of a given reflection $h k l$ and the sum is over all reflections and observations; $R_{\text {model }}=\frac{\sum_{h k l}|| F_{o, h k l}|-| F_{c, h k l}||}{\sum_{h k l}\left|F_{o, h k l}\right|}$, where $\left|F_{o, h k l}\right|$ and $\left|F_{c, h k l}\right|$ are respectively the observed structure factors and the ones calculated from the model for a given reflection $h k l$ and the sum is over all reflections $h k l$. The bias-free $\mathrm{R}_{\text {free }}$ was calculated on $5 \%$ of the data that were excluded from the refinement calculations.

\begin{tabular}{|c|c|c|}
\hline Compound & 14 & 19 \\
\hline PDB code & 6TF6 & $6 \mathrm{TF7}$ \\
\hline station & I911-3 & I911-2 \\
\hline \multirow[t]{2}{*}{ wavelength $(\AA)$} & 1.000 & 1.03841 \\
\hline & $\mathrm{a}=35.85$ & $\mathrm{a}=36.14$ \\
\hline \multirow[t]{2}{*}{ unit cell $(\AA)$} & $\mathrm{b}=57.34$ & $\mathrm{~b}=58.16$ \\
\hline & $c=62.04$ & $c=62.84$ \\
\hline Space group & $\mathrm{P} 2{ }_{1}{ }_{1} 2_{1}$ & $\mathrm{P} 2{ }_{1} 2_{1} 2_{1}$ \\
\hline \multirow{2}{*}{ resolution range $(\AA)$} & $31.0-1.5$ & $29.1-1.4$ \\
\hline & $(1.54-1.50)$ & $(1.44-1.4)$ \\
\hline completeness (\%) & $98.8(96.3)$ & $99.6(96.8)$ \\
\hline Total reflections & $74,804(6175)$ & $155,192(7866)$ \\
\hline unique reflections & $20,755(1522)$ & $26,601(1923)$ \\
\hline multiplicity & $3.6(3.4)$ & $5.8(4.2)$ \\
\hline $\mathrm{R}_{\text {merge }}(\%)$ & $0.073(0.725)$ & $0.048(0.519)$ \\
\hline mean $\mathrm{I} / \sigma(\mathrm{I})$ & $12.6(1.8)$ & $24.0(2.8)$ \\
\hline Wilson B-factor $\left(\AA^{2}\right)$ & 15.6 & 14.6 \\
\hline refinement program & Refmac5 & Refmac5 \\
\hline $\mathrm{R}_{\text {model }}(\mathrm{F} ; \%)$ & $0.116(0.173)$ & $0.135(0.240)$ \\
\hline $\mathrm{R}_{\text {free }}(\mathrm{F} ; \%)$ & $0.174(0.275)$ & $0.187(0.324)$ \\
\hline reflections used in refinement & $19,717(1374)$ & $25,272(1767)$ \\
\hline \multirow[t]{2}{*}{$\left(\right.$ for $\left.R_{\text {free }}\right)$} & $1038(72)$ & $1330(93)$ \\
\hline & protein: 14.2 & protein: 13.5 \\
\hline \multirow[t]{2}{*}{ average B-factors $\left(\AA^{2}\right)$} & ligand: 21.5 & ligand: 19.4 \\
\hline & solvent: 33.4 & solvent: 28.9 \\
\hline Ramachandran outliers (\%) & 1 & 0 \\
\hline rotamer outliers (no. and \%) & $1,0.6 \%$ & $0,0.0 \%$ \\
\hline MolProbity clash score & 2.48 & 2.12 \\
\hline bond length rmsd from ideal ( & 0.020 & 0.019 \\
\hline bond angle rmsd from ideal $\left({ }^{\circ}\right)$ & 2.1 & 2.2 \\
\hline
\end{tabular}



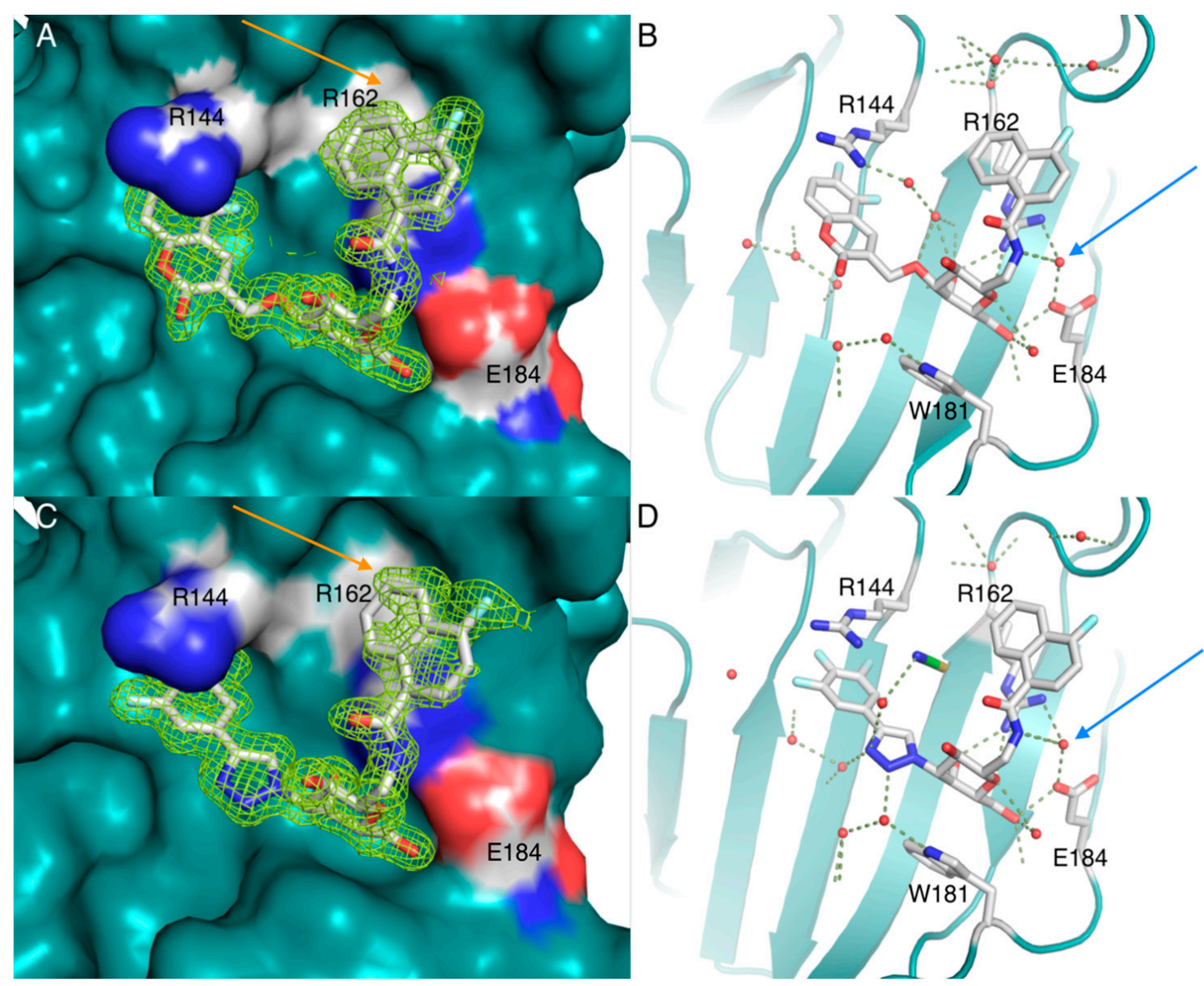

Figure 2. Electron densities of (A) 14 and (C) 19 in complex with galectin-3 (pdb id 6TF6 and 6TF7). Interactions of (B) 14 and (D) 19 in complex with galectin-3. The galectin-3-unique naphthyl-binding pocket above the $\beta$-face of the galactose residues is indicated with orange arrows and the water molecule hydrogen binding the amide $\mathrm{NH}$ and short-cutting the R162 and E184 salt-bridge analogously to ligand lactose $\mathrm{HO} 3$ is indicated with blue arrows.

Interestingly, the amide $\mathrm{NH}$ of both $\mathbf{1 4}$ and $\mathbf{1 9}$ formed a hydrogen bond to a water molecule short-cutting a salt-bridge between R162 and E184 (Figure 2B,D and Figure 3A). In natural ligands, for example lactose, this salt bridge is short-cut by the $\mathrm{HO} 3$ of the glucose subunit of lactose (Figure 3B). Hence, the amide $\mathrm{NH}$ of $\mathbf{1 4}$ and $\mathbf{1 9}$ hydrogen bonding to water mimics the similar hydrogen bonding pattern formed by, e.g., lactose or lacNAc-containing natural glycoconjugate ligands (Figure 3C). Furthermore, the hydrogen bond network with R162, E184, the water molecule, and 14 or 19 extends via the ligand amide oxygen to accept a hydrogen bond from the galactose $\mathrm{HO} 2$ (Figure 3A). This extended hydrogen bond network represents adds to the high 14- and 19-galectin-3 complex complementarity, which possibly contributes to the good affinity of $\mathbf{1 4}$ and 19 for galectin-3. 

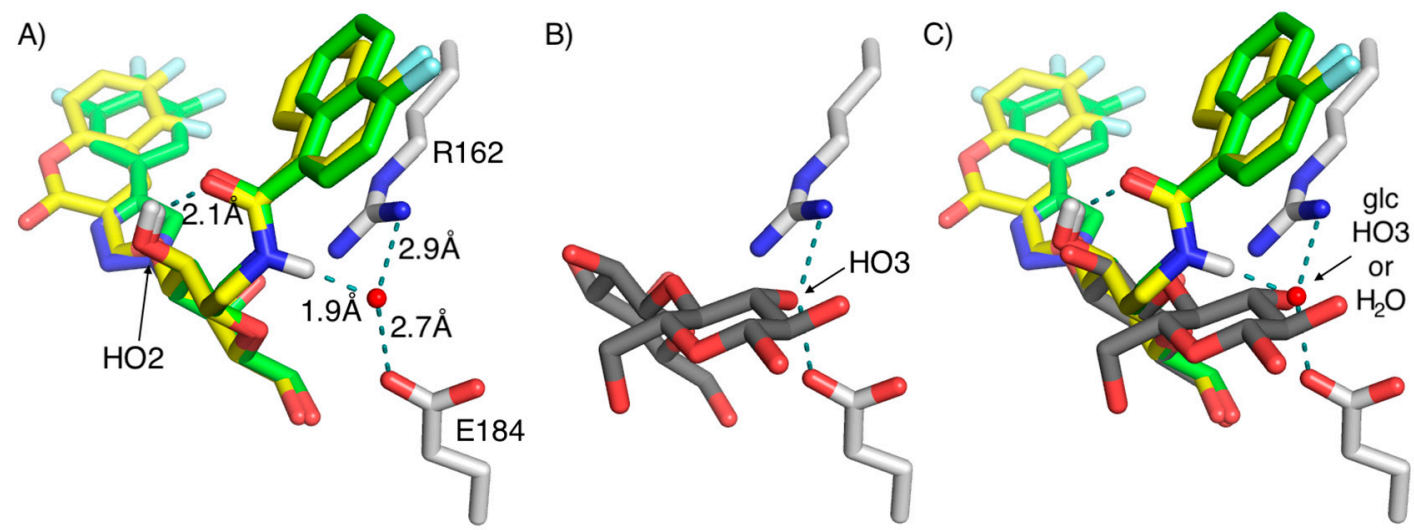

Figure 3. (A) The amide NH of $\mathbf{1 4}$ (yellow carbons) and $\mathbf{1 9}$ (green carbons) hydrogen binds a water molecule that short-cuts the R162-E184 salt-bridge in galectin-3. This hydrogen bonding network extends via the amide carbonyl to the ligand galactose $\mathrm{HO} 2$ (indicated with arrow). (B) The glucose $\mathrm{HO} 3$ (indicated with arrow) of lactose (grey carbons) replaces the water that short-cuts the R162-E184 salt-bridge in galectin-3 (from pdb id 3ZSJ [31]). (C) Overlay of 14, 19, and lactose showing that the lactose HO3 is positioned to short-cut the R162-E184 salt-bridge in the same way as the $\mathbf{1 4}$ and $\mathbf{1 9}$ amide $\mathrm{NH}$ hydrogen bonded water molecule.

\section{Conclusions}

In conclusion, 1-naphthamido C- $\beta$-galactosyls have been synthesized and discovered to bind galectin-3 with high affinity and selectivity. The affinity enhancements and high selectivity stems from three factors. First, the 1-naphthamido moieties binding a pocket unique to galectin-3 and perpendicular to the core galactose binding site, in which it stacks onto the side chain and the guanidinium group of R162. Second, the trifluorophenyltriazolyl- and difluorocoumaryl-moieties at the galactose C3/O3 of 14 and 19, respectively, are known to form affinity-enhancing stacking interactions with R144, as well as to confer selectivity for galectin-3. Finally, the amide NH-water mediated hydrogen bonds to R162 and E184 may not necessarily induce selectivity as is mimics a conserved hydrogen bonding motif involving the glucose or $\mathrm{N}$-acetylglucosamine 3-OH of lactose or lacNAc as parts of endogenous ligands binding to several different galectins, but it apparently enhances affinity as seen when the amide 4 is compared to the oxime 1 , oxazole 2 , and alkene 3 .

\section{Materials and Methods}

\section{General}

NMR spectra were recorded on a Bruker Avance II $400 \mathrm{MHz}$ spectrometer (Fällanden, Switzerland) at ambient temperature. ${ }^{1} \mathrm{H}-\mathrm{NMR}$ spectra were assigned using $2 \mathrm{D}$-methods (COSY). Chemical shifts are given in ppm downfield from the signal for $\mathrm{Me}_{4} \mathrm{Si}$, with reference to residual $\mathrm{CHCl}_{3}$ or $\mathrm{CD}_{2} \mathrm{HOD}$. High resolution mass spectrometry (HRMS) was determined by direct infusion on a Waters XEVO-G2 QTOF mass spectrometer (Waters, Milfor, MA, USA) using electrospray ionization (ESI). Reactions were monitored by TLC using aluminum-backed silica gel plates (Merck $60 \mathrm{~F}_{254}$, Darmstadt, Germany) and visualized using UV light and by charring with ethanolic $\mathrm{H}_{2} \mathrm{SO}_{4}(7 \%)$. Preparative chromatography was performed using silica gel $(40-60 \mu \mathrm{m}, 60 \AA)$ columns. Solvents were dried by storing over activated M.S. Reagents were supplied by Sigma-Aldrich and used as is.

(E) 3-( 3 -D-galactopyranosyl)-1-(naphthalen-1-yl)-1-propene 3:

To a solution of 5 (30 mg, $0.081 \mathrm{mmol}$ ) and Grubbs catalyst 2nd generation ( $3.4 \mathrm{mg}, 0.0041 \mathrm{mmol})$ in $\mathrm{CH}_{2} \mathrm{Cl}_{2}(5 \mathrm{~mL})$ was added 1-vinylaphthalene $(62.5 \mathrm{mg}, 0.405 \mathrm{mmol}, 5 \mathrm{eq})$ and the resulting mixture was refluxed overnight. The solvent was evaporated and the residue dissolved in $\mathrm{MeOH}(5 \mathrm{~mL})$, and $\mathrm{NaOMe}(1 \mathrm{M}, 1 \mathrm{~mL})$ was added. The mixture was stirred overnight, the $\mathrm{pH}$ was adjusted to 7 by 
addition of DOWEX 50W $\mathrm{H}^{+}$, and the solvent was evaporated. The residue was purified by flash chromatography $\left(\mathrm{CH}_{2} \mathrm{Cl}_{2}: \mathrm{MeOH} 9: 1\right)$ to give $3(20 \mathrm{mg}, 75 \%)$. [ $\left.\alpha\right]_{\mathrm{D}}{ }^{20}-3.0($ c $1.32, \mathrm{MeOH}) .{ }^{1} \mathrm{H}$ NMR $\left(\mathrm{CDCl}_{3}\right): \delta 8.17(\mathrm{~d}, J$ 8.0, $1 \mathrm{H}, \mathrm{Ph}), 7.83(\mathrm{~d}, J$ 8.0, $1 \mathrm{H}, \mathrm{Ph}), 7.73(\mathrm{~d}, J$ 8.1, $1 \mathrm{H}, \mathrm{Ph}), 7.61(\mathrm{~d}, J$ 7.1, $1 \mathrm{H}, \mathrm{Ph})$, 7.50-7.39 (m, 3H, Ph), 7.25 (d, J 15.5, 1H, CH), $6.44(\mathrm{dt}, J$ 15.6, 7.0, 1H, CH), 3.90 (d, J 3.3, 1H, H-4), 3.77 (dd, J 11.3, 6.8, 1H, H-6), 3.71 (dd, J 11.3, 5.4, 1H, H-6), 3.56 (t, J 9.3, 1H, H-2), 3.51 (t, J 6.1, 1H, H-5), 3.47 (dd, J 9.3, 3.3, 1H, H-3), 3.33 (obscured by $\left.\mathrm{CD}_{2} \mathrm{HOD}, \mathrm{H}-1\right), 2.88\left(\mathrm{dd}, J 14.9,7.0,1 \mathrm{H}, \mathrm{CH}_{2}\right), 2.57(\mathrm{~m}, 1 \mathrm{H}$, $\left.\mathrm{CH}_{2}\right) .{ }^{13} \mathrm{C} \mathrm{NMR}\left(\mathrm{CDCl}_{3}\right): \delta 131.5,130.0,129.4,128.3,126.8,126.6,125.0,124.5,81.5,80.3,76.5,72.3,71.0$, 62.9, 36.6. HRMS calcd for $\mathrm{C}_{19} \mathrm{H}_{22} \mathrm{O}_{5} \mathrm{Na}(\mathrm{M}+\mathrm{Na})^{+}: 353.1365$ : found: 353.1368 .

Typical procedure for the synthesis of the compounds 4 and 7-11: 1-(4-Fluoro-naphth-1-amido)2,6-anhydro-l-deoxy-D-glycero-L-manno-heptitol 7:

To a solution of 1-C-aminomethyl-galactose 6 [11] $(0.47 \mathrm{~g}, 2.43 \mathrm{mmol})$ in water $(15 \mathrm{~mL})$ was added a solution of 4-fluoro-1-naphthoyl chloride $(0.76 \mathrm{~g}, 3.64 \mathrm{mmol})$ in THF $(4 \mathrm{~mL})$ followed by the addition of $\mathrm{Na}_{2} \mathrm{CO}_{3}(390 \mathrm{mg}, 3.64 \mathrm{mmol})$. The reaction mixture was left overnight at room temperature. The solvent was evaporated and purified by flash chromatography $\left(\mathrm{SiO}_{2}, \mathrm{CH}_{2} \mathrm{Cl}_{2}: \mathrm{MeOH}\right.$ 10:1) to afford pure $7(0.102 \mathrm{~g}, 12 \%)$ as a colorless foam. The yield of 7 is apparently low due to the presence of residual inseparable aluminum salts in C-galactosyl 5 resulting from its synthesis by $\mathrm{LiAlH}_{4}$ reduction of the preceding nitrile, as originally also reported by Coxon and co-workers [11]. [ $\alpha]_{\mathrm{D}}{ }^{25}+10.5$ (c 1.1 in $\mathrm{MeOH}),{ }^{1} \mathrm{H}$ NMR (400 MHz, CD $\left.{ }_{3} \mathrm{OD}\right)$ 8: 8.29-8.27 (m, 1H, ArH), 8.14-8.12 (m, 1H, ArH), 7.67-7.61 (m, $3 \mathrm{H}, \mathrm{ArH}), 7.25(\mathrm{t}, 1 \mathrm{H}, J 8.0 \mathrm{~Hz}, \mathrm{ArH}), 4.05(\mathrm{t}, 1 \mathrm{H}, J 2.8 \mathrm{~Hz}, \mathrm{H}-1), 3.85(\mathrm{~d}, 1 \mathrm{H}, J 2.4 \mathrm{~Hz}, \mathrm{H}-4), 3.78(\mathrm{dd}, 1 \mathrm{H}, J$ 8.0, 7.5 Hz, H-6a), 3.66-3.48 (m, 5H, H-6b, H-2, H-3, $\left.\mathrm{CH}_{2} \mathrm{NH}, \mathrm{H}-5\right), 3.41-3.36$ (m, $\left.1 \mathrm{H}, \mathrm{CH}_{2} \mathrm{NH}\right) .{ }^{13} \mathrm{C}$ NMR

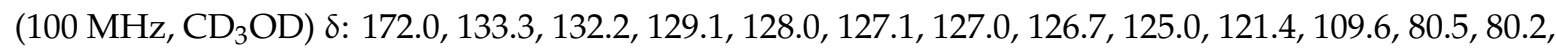
76.08, 71.06, 70.2, 63.2, 42.5. HRMS calcd for $\mathrm{C}_{18} \mathrm{H}_{20} \mathrm{FNO}_{6} \mathrm{Na}(\mathrm{M}+\mathrm{Na})^{+}$: 388.1172, found: 388.1176.

Compounds 4, 8-11 were synthesized following the same procedure:

1-(Naphth-1-amido)-2,6-anhydro-l-deoxy-D-glycero-L-manno-heptitol 4:

1-Naphthoyl chloride gave $30 \mathrm{mg}(11 \%)$ of $4 .[\alpha]_{\mathrm{D}}{ }^{25}+12.5$ (c 1.3 in $\left.\mathrm{MeOH}\right),{ }^{1} \mathrm{H}$ NMR $(400 \mathrm{MHz}$, $\left.\mathrm{CD}_{3} \mathrm{OD}\right)$ 8: $8.22(\mathrm{dd}, 1 \mathrm{H}, J$ 1.6, $0.4 \mathrm{~Hz}, \mathrm{ArH}), 7.98(\mathrm{~d}, 1 \mathrm{H}, J 8.4 \mathrm{~Hz}, \mathrm{ArH}), 7.92(\mathrm{dd}, 1 \mathrm{H}, J$ 2.8, $2.0 \mathrm{~Hz}, \mathrm{ArH})$, $7.65(\mathrm{dd}, 1 \mathrm{H}, J 1.2 \mathrm{~Hz}, \mathrm{ArH}), 7.58-7.49$ (m, 3H, ArH), 4.07 (dd, 1H, J 2.4 Hz, H-1), 3.85 (d, 1H, J 2.4 Hz, H-4), 3.78 (dd, $1 \mathrm{H}, J$ J 8.0, 7.6 Hz, H-6a), 3.65-3.48 (m, 5H, H-6b, H-2, H-3, $\left.\mathrm{CH}_{2} \mathrm{NH}, \mathrm{H}-5\right), 3.41-3.36$ (m, $\left.1 \mathrm{H}, \mathrm{CH}_{2} \mathrm{NH}\right) .{ }^{13} \mathrm{C}$ NMR $\left(100 \mathrm{MHz}, \mathrm{CD}_{3} \mathrm{OD}\right) \delta: 172.8,135.8,135.1,131.5,131.4,129.4,128.0,127.4,126.4$, 126.4, 126.0, 80.5, 80.3, 76.1, 71.1, 70.2, 63.2, 42.5. HRMS calcd for $\mathrm{C}_{18} \mathrm{H}_{21} \mathrm{NO}_{6} \mathrm{Na}(\mathrm{M}+\mathrm{Na})^{+}$: 370.1267, found: 370.1270 .

1-(5-Fluoro-naphth-1-amido)-2,6-anhydro-l-deoxy-D-glycero-L-manno-heptitol 8:

5-Fluoro-1-naphthoyl chloride gave $28 \mathrm{mg}(11 \%)$ of 8 . $[\alpha]_{\mathrm{D}}{ }^{25}+9.7$ (c 1.2 in $\left.\mathrm{MeOH}\right),{ }^{1} \mathrm{H}$ NMR $(400$ $\left.\mathrm{MHz}, \mathrm{CD}_{3} \mathrm{OD}\right) \delta: 8.76(\mathrm{~m}, 1 \mathrm{H}, \mathrm{NH}), 8.20(\mathrm{~d}, 1 \mathrm{H}, J 8.4 \mathrm{~Hz}, \mathrm{ArH}), 8.03(\mathrm{~d}, 1 \mathrm{H}, J 8.4 \mathrm{~Hz}, \mathrm{ArH}), 7.73(\mathrm{t}, 1 \mathrm{H}, J$ $1.2 \mathrm{~Hz}, \mathrm{ArH}), 7.63(\mathrm{t}, 1 \mathrm{H}, J 6.8 \mathrm{~Hz}, \mathrm{ArH}), 7.55-7.50(\mathrm{~m}, 1 \mathrm{H}, \mathrm{ArH}), 7.27-7.23(\mathrm{~m}, 1 \mathrm{H}, \mathrm{ArH}), 4.07-4.02(\mathrm{~m}$, $1 \mathrm{H}, \mathrm{H}-1), 3.85$ (d, 1H, J $2.8 \mathrm{~Hz}, \mathrm{H}-4), 3.78$ (dd, 1H, J 8.0, 7.6 Hz, H-6a), 3.66-3.48 (m, 5H, H-6b, H-2, $\left.\mathrm{H}-4, \mathrm{CH}_{2} \mathrm{NH}, \mathrm{H}-5\right), 3.41-3.36\left(\mathrm{~m}, 1 \mathrm{H}, \mathrm{CH}_{2} \mathrm{NH}\right) .{ }^{13} \mathrm{C} \mathrm{NMR}\left(100 \mathrm{MHz}, \mathrm{CD}_{3} \mathrm{OD}\right) \delta: 172.3,135.9,132.9$, 128.0, 127.5, 126.6, 125.2, 125.0, 123.3, 122.7, 111.0, 80.5, 80.2, 76.1, 71.1, 70.2, 63.2, 42.5. HRMS calcd for $\mathrm{C}_{18} \mathrm{H}_{20} \mathrm{FNO}_{6} \mathrm{Na}(\mathrm{M}+\mathrm{Na})^{+}: 388.1172$, found: 388.1173 .

1-(6-Fluoro-naphth-1-amido)-2,6-anhydro-1-deoxy-D-glycero-L-manno-heptitol 9:

6-Fluoro-1-naphthoyl chloride gave $57 \mathrm{mg}(8 \%)$ of $9 .[\alpha]_{\mathrm{D}}^{25}+10.7$ (c 1.4 in $\left.\mathrm{MeOH}\right),{ }^{1} \mathrm{H}$ NMR $\left(400 \mathrm{MHz}, \mathrm{CD}_{3} \mathrm{OD}\right) \delta: 8.29(\mathrm{t}, 1 \mathrm{H}, J 5.6 \mathrm{~Hz}, \mathrm{ArH}), 7.96(\mathrm{~d}, 1 \mathrm{H}, J 8.0 \mathrm{~Hz}, \mathrm{ArH}), 7.63-7.53(\mathrm{~m}, 3 \mathrm{H}, \mathrm{ArH})$, 7.41-7.35 (m, 1H, ArH), 4.05 (t, 1H, J $2.8 \mathrm{~Hz}, \mathrm{H}-1), 3.86(\mathrm{t}, 1 \mathrm{H}, J 0.8 \mathrm{~Hz}, \mathrm{H}-4), 3.78(\mathrm{dd}, 1 \mathrm{H}, J$ 8.0, 7.6 $\mathrm{Hz}, \mathrm{H}-6 \mathrm{a}), 3.66-3.48$ (m, 5H, H-6b, H-2, H-5, $\left.\mathrm{CH}_{2} \mathrm{NH}, \mathrm{H}-3\right), 3.41-3.36$ (m, $\left.1 \mathrm{H}, \mathrm{CH}_{2} \mathrm{NH}\right) .{ }^{13} \mathrm{C}$ NMR $(100$ $\left.\mathrm{MHz}, \mathrm{CD}_{3} \mathrm{OD}\right) \delta:$ : 172.5, 136.2, 136.1, 135.9, 130.8, 129.5, 128.5, 127.2, 125.8, 118.1, 112.3, 80.5, 80.2, 76.1, $71.1,70.2,63.2,42.5$. HRMS calcd for $\mathrm{C}_{18} \mathrm{H}_{20} \mathrm{FNO}_{6} \mathrm{Na}(\mathrm{M}+\mathrm{Na})^{+}: 388.1172$, found: 388.1174 . 
1-(5-Bromo-naphth-1-amido)-2,6-anhydro-1-deoxy-D-glycero-L-manno-heptitol 10:

6-Bromo-1-naphthoyl chloride gave $18 \mathrm{mg}(3 \%)$ of 10. $[\alpha]_{\mathrm{D}}{ }^{25}+7.7$ (c $\left.1.4 \mathrm{in} \mathrm{MeOH}\right),{ }^{1} \mathrm{H}$ NMR $(400$ $\left.\mathrm{MHz}, \mathrm{CD}_{3} \mathrm{OD}\right) \delta: 8.37(\mathrm{~d}, 1 \mathrm{H}, J 8.4 \mathrm{~Hz}, \mathrm{ArH}), 8.22(\mathrm{~d}, 1 \mathrm{H}, J 8.4 \mathrm{~Hz}, \mathrm{ArH}), 7.88(\mathrm{dd}, 1 \mathrm{H}, J$ 1.2, $0.8 \mathrm{~Hz}$, ArH), 7.72-7.64 (m, 2H, ArH), $7.46(\mathrm{dd}, 1 \mathrm{H}, J$ 7.6, 7.2 Hz, ArH), $4.06(\mathrm{t}, 1 \mathrm{H}, J 2.4 \mathrm{~Hz}, \mathrm{H}-1), 3.85(\mathrm{~d}, 1 \mathrm{H}, J$ $2.4 \mathrm{~Hz}, \mathrm{H}-4), 3.78$ (t, 1H, J $8.0 \mathrm{~Hz}, \mathrm{H}-6 \mathrm{a}), 3.66-3.48$ (m, 5H, H-6b, H-2, H-3, $\left.\mathrm{CH}_{2} \mathrm{NH}, \mathrm{H}-5\right), 3.41-3.36$ (m, $\left.1 \mathrm{H}, \mathrm{CH}_{2} \mathrm{NH}\right) .{ }^{13} \mathrm{C}$ NMR $\left(100 \mathrm{MHz}, \mathrm{CD}_{3} \mathrm{OD}\right) \delta: 172.2,136.7,133.2,132.8,131.7,130.0,128.4,127.6$, 127.3, 126.7, $123.8,80.5,80.2,76.1,71.1,70.2,63.2,42.5$. HRMS calcd for $\mathrm{C}_{18} \mathrm{H}_{20} \mathrm{BrNO}_{6} \mathrm{Na}(\mathrm{M}+\mathrm{Na})^{+}$: 448.0372, found: 448.0371 .

1-(4-Methoxy-naphth-1-amido)-2,6-anhydro-l-deoxy-D-glycero-L-manno-heptitol 11:

4-Methoxy-1-naphthoyl chloride gave $142 \mathrm{mg}(14 \%)$ of 11. $[\alpha]_{\mathrm{D}}{ }^{25}+11.4$ (c $\left.1.7 \mathrm{in} \mathrm{MeOH}\right),{ }^{1} \mathrm{H}$ NMR $\left(400 \mathrm{MHz}, \mathrm{CD}_{3} \mathrm{OD}\right) \delta: 8.56(\mathrm{~m}, 1 \mathrm{H}, \mathrm{NH}), 8.28(2 \mathrm{~d}, 2 \mathrm{H}, J 9.6$ and $8.8 \mathrm{~Hz}, \mathrm{ArH}), 7.64(\mathrm{~d}, 1 \mathrm{H}, J 8.0 \mathrm{~Hz}, \mathrm{ArH})$, 7.58-7.47 (m, 2H, ArH), $6.92(\mathrm{~d}, 1 \mathrm{H}, J 8.0 \mathrm{~Hz}, \mathrm{ArH}), 4.03\left(\mathrm{~s}, 3 \mathrm{H},-\mathrm{OCH}_{3}\right), 4.01-3.99(\mathrm{~m}, 1 \mathrm{H}, \mathrm{H}-1), 3.84(\mathrm{~d}$, $1 \mathrm{H}, J 2.4 \mathrm{~Hz}, \mathrm{H}-4), 3.78$ (t, 1H, J 7.6 Hz, H-6a), 3.65-3.48 (m, 5H, H-6b, H-2, H-3, CH $\left.{ }_{2} \mathrm{NH}, \mathrm{H}-5\right), 3.39-3.34$ $\left(\mathrm{m}, 1 \mathrm{H}, \mathrm{CH}_{2} \mathrm{NH}\right) .{ }^{13} \mathrm{C}$ NMR $\left(100 \mathrm{MHz}, \mathrm{CD}_{3} \mathrm{OD}\right) \delta: 173.0,158.5,132.7,128.4,127.9,127.8,126.8,126.6$, $126.3,123.1,103.7,80.5,80.3,76.1,71.1,70.2,63.2,56.3,42.5$. HRMS calcd for $\mathrm{C}_{19} \mathrm{H}_{23} \mathrm{NO}_{7} \mathrm{Na}(\mathrm{M}+\mathrm{Na})^{+}$: 400.1372, found: 400.1377 .

1-(4-Fluoro-naphth-1-amido)-2,6-anhydro-4-O-propargyl-1-deoxy-D-glycero-L-manno-heptitol 12:

Compound 6 (0.5 g, $1.36 \mathrm{mmol})$ was dissolved in dry $\mathrm{MeOH}(10 \mathrm{~mL})$ and $n-\mathrm{Bu}_{2} \mathrm{SnO}(0.405 \mathrm{~g}, 1.63$ mmol) was added. The mixture was refluxed at $70^{\circ} \mathrm{C}$ for $3 \mathrm{~h}$, where after the solvent was evaporated under reduced pressure. To the residue were added 1,4-dioxane $(20 \mathrm{~mL})$, propargyl bromide $(365 \mu \mathrm{L}$, $4.08 \mathrm{mmol})$ and $n-\mathrm{Bu}_{4} \mathrm{NBr}(0.52 \mathrm{~g}, 1.63 \mathrm{mmol})$. The mixture was sonicated for $10 \mathrm{~min}$ and then refluxed overnight at $100{ }^{\circ} \mathrm{C}$. Completion of reaction was checked by TLC $\left(\mathrm{CH}_{2} \mathrm{Cl}_{2}: \mathrm{MeOH} 6: 1\right)$. The solvent was evaporated under reduced pressure and the sticky residue was dissolved in $\mathrm{MeOH}$ to obtain a slurry and purified by flash chromatography $\left(\mathrm{SiO}_{2}, \mathrm{CH}_{2} \mathrm{Cl}_{2}\right.$ : $\mathrm{MeOH}$ 17:1) to afford compound $12(0.434 \mathrm{~g}, 79 \%)$. $[\alpha]_{\mathrm{D}}{ }^{25}+9.1($ c 0.54 in $\mathrm{MeOH}),{ }^{1} \mathrm{H}$ NMR $\left(400 \mathrm{MHz}, \mathrm{CD}_{3} \mathrm{OD}\right) \delta: 8.28(\mathrm{dd}, 1 \mathrm{H}, J$ 2.0, $1.6 \mathrm{~Hz}, \mathrm{ArH}), 8.14$ (dd, $1 \mathrm{H}, J$ 2 $.8,2.0 \mathrm{~Hz}, \mathrm{ArH}), 7.67-7.61(\mathrm{~m}, 3 \mathrm{H}, \mathrm{ArH}), 7.25(\mathrm{t}, 1 \mathrm{H}, J 8.0 \mathrm{~Hz}, \mathrm{ArH}), 4.40(\mathrm{dd}, 2 \mathrm{H}, J 3.9,2.4 \mathrm{~Hz}$, $\left.\mathrm{CH}_{2} \mathrm{CCH}\right), 4.10(\mathrm{~d}, 1 \mathrm{H}, J 2.8 \mathrm{~Hz}, \mathrm{H}-4), 4.05\left(\mathrm{dd}, 1 \mathrm{H}, J\right.$ J 13.6, $\left.2.8 \mathrm{~Hz}, \mathrm{CH}_{2} \mathrm{NH}\right), 3.78-3.51(\mathrm{~m}, 6 \mathrm{H}, \mathrm{H}-6 \mathrm{a}, \mathrm{H}-5$, $\left.\mathrm{H}-6 \mathrm{~b}, \mathrm{CH}_{2} \mathrm{NH}, \mathrm{H}-2, \mathrm{H}-3\right), 3.46-3.41$ (m, 1H, H-1), 2.89 (t, $\left.1 \mathrm{H}, J 2.4 \mathrm{~Hz}, \mathrm{HCCCH}_{2}\right) .{ }^{13} \mathrm{C}$ NMR $(100 \mathrm{MHz}$, $\left.\mathrm{CD}_{3} \mathrm{OD}\right) \delta: 172.0,133.2,132.2,129.1,127.97,127.95,127.1,126.7,125.0,121.4,109.6,83.0,81.0,80.3,80.2$, 76.1, 69.1, 67.9, 63.1, 57.7, 42.5. HRMS calcd for $\mathrm{C}_{21} \mathrm{H}_{22} \mathrm{FNO}_{6} \mathrm{Na}(\mathrm{M}+\mathrm{Na})^{+}: 426.1329$, found: 426.1331 .

1-(4-Fluoro-naphth-1-amido)-3,5,7-tri-O-acetyl-2,6-anhydro-4-O-propargyl-1-deoxy-D-glycero-Lmanno-heptitol 13:

Compound $12(0.315 \mathrm{~g}, 0.78 \mathrm{mmol})$ was dissolved in pyridine $(10 \mathrm{~mL})$ and acetic anhydride $(10 \mathrm{~mL})$, stirred for $2 \mathrm{~h}$, evaporated, and the residue was purified by column chromatography $\left(\mathrm{SiO}_{2}\right.$, heptane:EtOAc 1:1) to give $13(0.388 \mathrm{~g}, 94 \%)$. $[\alpha]_{\mathrm{D}}{ }^{25}+16.2\left(c 1.1\right.$ in $\left.\mathrm{CHCl}_{3}\right),{ }^{1} \mathrm{H}$ NMR $\left(400 \mathrm{MHz}, \mathrm{CDCl}_{3}\right)$

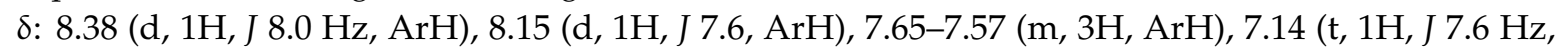
ArH), 6.37 (m, 1H, NH), 5.46 (dd, 1H, J 3.5, 1.0 Hz, H-4), 5.11 (t, 1H, J 10.0 Hz, H-3), 4.20 (d, 2H, J 2.4 $\left.\mathrm{Hz}, \mathrm{OCH}_{2} \mathrm{CCH}\right), 4.11$ (dd, 2H, J 2.4, $\left.1.6 \mathrm{~Hz}, \mathrm{H}-6 \mathrm{a}, \mathrm{H}-6 \mathrm{~b}\right), 4.05-3.99\left(\mathrm{~m}, 1 \mathrm{H}, \mathrm{CH}_{2} \mathrm{NH}\right), 3.89-3.86(\mathrm{~m}, 2 \mathrm{H}$, H-3, H-5), 3.73-3.68 (m, 1H, H-1), 3.47-3.41 (m, 1H, OCH $\left.{ }_{2} \mathrm{CCH}\right), 2.46\left(\mathrm{t}, 1 \mathrm{H}, J 2.4 \mathrm{~Hz}, \mathrm{HCCCH}_{2}\right), 2.16$, 2.08, 1.96 (s, 9H, $\left.3 \times \mathrm{COCH}_{3}\right) .{ }^{13} \mathrm{C}$ NMR $\left(100 \mathrm{MHz}, \mathrm{CDCl}_{3}\right) \delta: 170.6,170.5,170.4,168.9,132.1,130.7$, 128.3, 127.0, 125.63, 125.57, 125.5, 124.1, 121.0, 108.6, 79.2, 76.9, 76.7, 75.2, 74.8, 68.1, 66.3, 62.3, 56.6, 40.5, 21.1, 20.9, 20.8. HRMS calcd for $\mathrm{C}_{27} \mathrm{H}_{28} \mathrm{FNO}_{9} \mathrm{Na}(\mathrm{M}+\mathrm{Na})^{+}: 552.1646$, found: 552.1650 .

1-(4-Fluoro-naphth-1-amido)-2,6-anhydro-4-O-(5,6-difluoro-2H-1-benzopyran-2-on-3-yl)-1-deoxyD-glycero-L-manno-heptitol 14:

Compound 13 (0.117 g, $0.22 \mathrm{mmol})$ was dissolved in dry THF $(10 \mathrm{~mL})$ to which $\mathrm{TsN}_{3}(0.052 \mathrm{~g}$, $0.264 \mathrm{mmol}), 5,6$-difluorosalicylaldehyde $(0.042 \mathrm{~g}, 0.264 \mathrm{mmol})$, and $\mathrm{CuI}(0.0042 \mathrm{~g}, 0.022 \mathrm{mmol})$ was 
added. After $5 \mathrm{~min}, \mathrm{Et}_{3} \mathrm{~N}(62 \mu \mathrm{L}, 0.44 \mathrm{mmol})$ was added to it resulting in the change of the color of the solution. The reaction mixture was left overnight and TLC was checked. After consumption of the starting material, the solution was evaporated and diluted with $\mathrm{CH}_{2} \mathrm{Cl}_{2}$. Work up was done with $\mathrm{NH}_{4} \mathrm{Cl}$ solution. The organic layer collected was evaporated and directly proceeded to the next step. The compound was dissolved in $\mathrm{MeOH}(5 \mathrm{~mL})$ and freshly prepared $\mathrm{NaOMe}(0.5 \mathrm{M}$ in $\mathrm{MeOH}, 100 \mathrm{~mL})$ was added to it and left for 2 days. After complete conversion of the starting material, the solution was neutralized with DOWEX 50W H+ resin, filtered, evaporated and purified by flash chromatography $\left(\mathrm{SiO}_{2}, \mathrm{CH}_{2} \mathrm{Cl}_{2}: \mathrm{MeOH} 20: 1\right)$ to afford colorless pure compound $14(0.050 \mathrm{~g}, 40 \%)$. $[\alpha]_{\mathrm{D}}{ }^{25}+3.7(c 0.33$ in $\mathrm{MeOH}),{ }^{1} \mathrm{H}$ NMR (400 MHz, CD $\left.{ }_{3} \mathrm{OD}\right) \delta: 8.37$ (s, 1H, ArH), 8.30-8.27 (m, 1H, ArH), 8.13-8.10 (m, 1H, ArH), 7.67-7.60 (m, 3H, ArH), 7.52-7.45 (m, 1H, ArH), 7.25-7.17 (m, 2H, ArH), 4.74 (dd, 1H, J 1.6 Hz, $\left.\mathrm{CH}_{2} \mathrm{Ph}\right), 4.61\left(\mathrm{t}, 1 \mathrm{H}, J 1.2 \mathrm{~Hz}, \mathrm{CH}_{2} \mathrm{Ph}\right), 4.18(\mathrm{~d}, 1 \mathrm{H}, J 2.4 \mathrm{~Hz}, \mathrm{H}-3), 4.08\left(\mathrm{dd}, 1 \mathrm{H}, J 2.8,2.4 \mathrm{~Hz}, \mathrm{CH}_{2} \mathrm{NH}\right)$, 3.83-3.77 (m, 2H, H-6a, H-5), 3.70-3.55 (m, 3H, H-6b, $\left.\mathrm{CH}_{2} \mathrm{NH}, \mathrm{H}-4\right), 3.52-3.41$ (m, 2H, H-2, H-1). ${ }^{13} \mathrm{C}$ NMR (100 MHz, CD $\left.{ }_{3} \mathrm{OD}\right)$ ): 172.0, 161.1, 159.7 133.2, 132.2, 132.0, 129.1, 128.0, 127.14, 127.05, 126.7, 125.0, 121.41, 121.35, 120.5, 120.3, 113.4, 109.6, 109.4, 84.7, 80.3, 80.2, 69.2, 67.6, 66.8, 63.2, 42.5. HRMS calcd for $\mathrm{C}_{28} \mathrm{H}_{24} \mathrm{~F}_{3} \mathrm{NO}_{8} \mathrm{Na}(\mathrm{M}+\mathrm{Na})^{+}$: 582.1352 , found: 582.1350 .

1-(4-Fluoro-naphth-1-amido)-2,6-anhydro-5,7-O-benzylidene-4-O-[3,5-bis-(trifluoromethyl)benzenesulfonyl]-l-deoxy-D-glycero-L-manno-heptitol 15:

Compound 7 (0.332 g, $0.908 \mathrm{mmol})$ was dissolved in DMF (10 mL) under nitrogen, followed by adding benzaldehyde dimethyl acetal $(204 \mu \mathrm{L}, 1.36 \mathrm{mmol})$ and a catalytic amount of $p$-toluene sulfonic acid. The reaction mixture was stirred for $2.5 \mathrm{~h}$ at room temperature and reaction completion was confirmed by TLC. Then the solution was diluted with ethyl acetate $(20 \mathrm{~mL})$ and washed successively with $\mathrm{H}_{2} \mathrm{O}(2 \times 10 \mathrm{~mL})$ and brine $(20 \mathrm{~mL})$. The organic layer was separated, dried $\left(\mathrm{Na}_{2} \mathrm{SO}_{4}\right)$ and evaporated as pale yellow syrup, which was pure enough to proceed to the next step. The compound ( $260 \mathrm{mg}, 0.57 \mathrm{mmol}$ ) was dissolved in THF (30 mL) to which $\mathrm{Bu}_{2} \mathrm{SnCl}_{2}(17 \mathrm{mg}, 0.057 \mathrm{mmol}$ ) was added under nitrogen atmosphere and the mixture was stirred at room temperature for $15 \mathrm{~min}$. A mixture of 1,1,2,2,6-pentamethylpiperidine ( $260 \mu \mathrm{L}, 1.14 \mathrm{mmol}$ ) and 3,5-bis-(trifluoromethyl)benzenesulfonyl chloride (197 mg, $0.63 \mathrm{mmol}$ ) in THF, was added to it. The mixture was stirred overnight at room temperature until the starting material was completely consumed (TLC). The solution was quenched by $\mathrm{NH}_{4} \mathrm{Cl}$ solution and the solvents were evaporated to give the crude product. The solution was then diluted with ethyl acetate $(20 \mathrm{~mL})$ and washed successively with $\mathrm{H}_{2} \mathrm{O}(2 \times 10 \mathrm{~mL})$ and brine $(10 \mathrm{~mL})$. The organic layer was separated, dried $\left(\mathrm{Na}_{2} \mathrm{SO}_{4}\right)$ and evaporated in vacuo. The crude product was purified by flash chromatography $\left(\mathrm{SiO}_{2}\right.$, heptane:EtOAc 1:1) to afford pure $15(216 \mathrm{mg}, 52 \%)$ as white foam. $[\alpha]_{\mathrm{D}}{ }^{25}+6.2\left(c 0.56\right.$ in $\left.\mathrm{CHCl}_{3}\right),{ }^{1} \mathrm{H} \mathrm{NMR}\left(400 \mathrm{MHz}, \mathrm{CDCl}_{3}\right) \delta: 8.45(\mathrm{~s}, 2 \mathrm{H}, \mathrm{ArH}), 8.24(\mathrm{~d}, 1 \mathrm{H}, J 8.0$ $\mathrm{Hz}, \mathrm{ArH}), 8.10-8.07(\mathrm{~m}, 2 \mathrm{H}, \mathrm{ArH}), 7.54(\mathrm{t}, 1 \mathrm{H}, J 7.2 \mathrm{~Hz}, \mathrm{ArH}), 7.45-7.33(\mathrm{~m}, 5 \mathrm{H}, \mathrm{ArH}), 7.24(\mathrm{dd}, 2 \mathrm{H}, J$ 8.0, 7.2 Hz, ArH), 6.67-6.61 (m, 2H, ArH), 5.58 (s, 1H, CHPh), 4.78 (dd, 1H, J 3.2 Hz, H-3), 4.56 (d, 1H, J $3.2 \mathrm{~Hz}, \mathrm{H}-4), 4.36-4.25$ (m, 3H, CH $\left.{ }_{2} \mathrm{NH}, \mathrm{H}-2, \mathrm{H}-6 \mathrm{a}\right), 4.08-4.02$ (m, 2H, H-5, H-6b), 3.58 (s, 2H, OH),

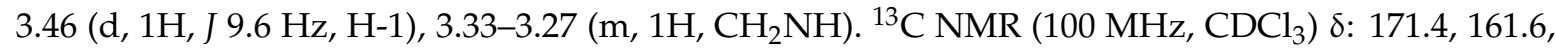
159.1, 139.6, 137.4, 132.9, 132.6, 131.82, 131.8, 129.2, 128.7, 128.4, 127.1, 126.4, 126.3, 126.0, 125.1, 124.1, $123.88,123.85,121.1,121.0,120.9,108.6,108.4,100.5,83.0,79.5,75.3,69.6,69.2,64.5,40.2$. HRMS calcd for $\mathrm{C}_{33} \mathrm{H}_{26} \mathrm{~F}_{7} \mathrm{NO}_{8} \mathrm{SNa}(\mathrm{M}+\mathrm{Na})^{+}:$752.1165, found: 752.1170 .

1-(4-Fluoro-naphth-1-amido)-3,4-di-O-acetyl-2,6-anhydro-5,7-O-benzylidene-1-deoxy-D-glyceroL-ido-heptitol 16:

To a solution of compound $15(216 \mathrm{mg}, 0.29 \mathrm{mmol})$ in dry pyridine $(10 \mathrm{~mL})$ was added $\mathrm{Ac}_{2} \mathrm{O}$ $(10 \mathrm{~mL})$ and stirring was continued for $2 \mathrm{~h}$ at room temperature until the starting material was completely consumed according to TLC analysis. The solvents were evaporated in vacuo and the residue $(198 \mathrm{mg}, 0.256 \mathrm{mmol})$ was dissolved in DMSO $(7 \mathrm{~mL})$ followed by addition of CsOAc $(147 \mathrm{mg}$, $0.769 \mathrm{mmol})$. The reaction mixture was stirred at $90{ }^{\circ} \mathrm{C}$ for 3 days until the starting material was completely consumed as confirmed by TLC. Then the reaction mixture was diluted by water $(10 \mathrm{~mL})$ 
and worked up with EtOAc $(3 \times 10 \mathrm{~mL})$. The organic layer was separated and dried over $\mathrm{Na}_{2} \mathrm{SO}_{4}$ and evaporated. It was purified by flash chromatography $\left(\mathrm{SiO}_{2}\right.$, hexane-EtOAc 1:1) to afford pure compound $16(41 \mathrm{mg}, 35 \%)$. $[\alpha]_{\mathrm{D}}{ }^{25}+5.9\left(\right.$ c 1.1 in $\left.\mathrm{CHCl}_{3}\right),{ }^{1} \mathrm{H}$ NMR $\left(400 \mathrm{MHz}, \mathrm{CDCl}_{3}\right)$ 8: 8.36-8.34 (m, $1 \mathrm{H}, \mathrm{ArH}), 8.12-8.09(\mathrm{~m}, 1 \mathrm{H}, \mathrm{ArH}), 7.58-7.52(\mathrm{~m}, 3 \mathrm{H}, \mathrm{ArH}), 7.40-7.32(\mathrm{~m}, 3 \mathrm{H}, \mathrm{ArH}), 7.27-7.23(\mathrm{~m}, 2 \mathrm{H}$, ArH), $6.93(\mathrm{dd}, 1 \mathrm{H}, J$ 8.0, 7.6 Hz, ArH), $6.56(\mathrm{t}, 1 \mathrm{H}, J 6.0 \mathrm{~Hz}, \mathrm{NH}), 5.53(\mathrm{~m}, 2 \mathrm{H}, \mathrm{CHPh}, \mathrm{H}-3), 5.29$ (dd, $1 \mathrm{H}, J$ 10.4, 3.2 Hz, H-2), 4.28 (dd, 1H, J 12.6, $1.7 \mathrm{~Hz}, \mathrm{H}-6 \mathrm{a}), 4.13-4.02$ (m, 2H, H-4, H-1), 4.05 (dd, 1H, J 12.6, $1.8 \mathrm{~Hz}, \mathrm{H}-6 \mathrm{~b}), 3.81-3.78\left(\mathrm{~m}, 2 \mathrm{H}, \mathrm{CH}_{2} \mathrm{NH}\right), 3.73$ (s, $\left.1 \mathrm{H}, \mathrm{H}-5\right), 2.18,2.09$ (s, 6H, $\left.2 \times \mathrm{COCH}_{3}\right) .{ }^{13} \mathrm{C}$ NMR $\left(100 \mathrm{MHz}, \mathrm{CDCl}_{3}\right)$ 8: 169.8, 169.6, 169.1, 161.3, 158.7, 137.3, 129.3, 128.4, 128.2, 126.9, 126.1, 125.73, 125.69, 125.67, 125.6, 120.8, 120.7, 108.6, 108.4, 101.1, 74.5, 72.1, 69.4, 67.9, 67.0, 65.9, 40.0, 21.0, 20.9. HRMS calcd for $\mathrm{C}_{29} \mathrm{H}_{28} \mathrm{FNO}_{8} \mathrm{Na}(\mathrm{M}+\mathrm{Na})^{+}: 560.1697$, found: 560.1699 .

1-(4-Fluoro-naphth-1-amido)-2,6-anhydro-5,7-O-benzylidene-1-deoxy-D-glycero-L-ido-heptitol 17:

Compound 16 (290 mg, $0.539 \mathrm{mmol})$ were dissolved in dry $\mathrm{MeOH}(10 \mathrm{~mL})$ to which $\mathrm{NaOMe}(0.5$ $\mathrm{M}$ in $\mathrm{MeOH}, 50 \mathrm{~mL}$ ) was added and the solution was allowed to stir at room temperature for $2 \mathrm{~h}$. The solution was neutralized with DOWEX $50 \mathrm{~W} \mathrm{H}^{+}$, filtered, and evaporated in vacuo to furnish pure compound $17(240 \mathrm{mg}, 98 \%)$ as amorphous white powder. $[\alpha]_{\mathrm{D}}{ }^{25}+11.9\left(c 1.4\right.$ in $\left.\mathrm{CHCl}_{3}\right),{ }^{1} \mathrm{H} \mathrm{NMR}$ $\left(400 \mathrm{MHz}, \mathrm{CDCl}_{3}\right) \delta: 8.32(\mathrm{~d}, 1 \mathrm{H}, J 8.4 \mathrm{~Hz}, \mathrm{ArH}), 8.11(\mathrm{~d}, 1 \mathrm{H}, J 8.0 \mathrm{~Hz}, \mathrm{ArH}), 7.55-7.46(\mathrm{~m}, 3 \mathrm{H}, \mathrm{ArH})$, 7.36-7.29 (m, 3H, ArH), 7.21 (t, 2H, J 7.6 Hz, ArH), 6.97-6.88 (m, 1H, NH), $6.82(\mathrm{t}, 1 \mathrm{H}, J 8.0 \mathrm{~Hz}, \mathrm{ArH})$, 5.51 (s, 1H, CHPh), 4.30-4.21 (m, 3H, CH $\left.{ }_{2} \mathrm{NH}, \mathrm{H}-6 \mathrm{a}, \mathrm{H}-2\right), 4.07-3.99$ (m, 2H, H-1, H-6b), 3.93-3.86 (m, $2 \mathrm{H}, \mathrm{H}-3, \mathrm{H}-4), 3.73$ (s, $1 \mathrm{H}, \mathrm{H}-5), 3.43-3.37\left(\mathrm{~m}, 1 \mathrm{H}, \mathrm{CH}_{2} \mathrm{NH}\right) .{ }^{13} \mathrm{C} \mathrm{NMR}\left(100 \mathrm{MHz}, \mathrm{CDCl}_{3}\right) \delta: 171.5,161.6$, 159.0, 138.0, 131.9, 129.1, 128.6, 128.3, 127.0, 126.3, 126.2, 126.1, 125.3, 120.94, 120.88, 108.6, 108.4, 100.7, $76.3,74.1,69.8,69.2,66.7,65.0,40.9$. HRMS calcd for $\mathrm{C}_{25} \mathrm{H}_{24} \mathrm{FNO}_{6} \mathrm{Na}(\mathrm{M}+\mathrm{Na})^{+}:$476.1485, found: 476.1489 .

1-(4-Fluoro-naphth-1-amido)-3-O-acetyl-2,6-anhydro-4-azido-5,7-O-benzylidene-1,4-dideoxy-Dglycero-L-manno-heptitol 18:

Compound $17(250 \mathrm{mg}, 0.551 \mathrm{mmol})$ was dissolved in in dry $\mathrm{CH}_{2} \mathrm{Cl}_{2}(10 \mathrm{~mL})$ followed by addition of pyridine $(89 \mu \mathrm{L}, 1.10 \mathrm{mmol})$ and $\mathrm{AcCl}(39 \mu \mathrm{L}, 0.551 \mathrm{mmol})$ to a stirred solution at room temperature under $\mathrm{N}_{2}$ atmosphere. After $2 \mathrm{~h}$, the mixture was washed with $\mathrm{NaHCO}_{3}(2 \times 10 \mathrm{~mL})$ and brine $(10 \mathrm{~mL})$. The combined aqueous phases were extracted with $\mathrm{CH}_{2} \mathrm{Cl}_{2}(2 \times 10 \mathrm{~mL})$. The organic phases were collected and dried over $\mathrm{Na}_{2} \mathrm{SO}_{4}$ and evaporated. The reaction mixture was directly dissolved in dry $\mathrm{CH}_{2} \mathrm{Cl}_{2}(10 \mathrm{~mL})$ and cooled to $-20^{\circ} \mathrm{C}$ followed by dropwise addition of $\mathrm{Tf}_{2} \mathrm{O}(182 \mu \mathrm{L}, 1.10 \mathrm{mmol})$. The reaction was stirred for $2 \mathrm{hr}$ and then allowed to reach room temperature. The mixture was then washed with $5 \% \mathrm{HCl}(2 \times 10 \mathrm{~mL})$ and brine $(10 \mathrm{~mL})$. The combined aqueous phases were extracted with $\mathrm{CH}_{2} \mathrm{Cl}_{2}(2 \times 10 \mathrm{~mL})$. The collected organic phases were dried over $\mathrm{Na}_{2} \mathrm{SO}_{4}$ and concentrated to give crude product. The crude product $(157 \mathrm{mg}, 0.250 \mathrm{mmol})$ was dissolved in DMSO $(10 \mathrm{~mL})$, followed by the addition of $\mathrm{NaN}_{3}(48 \mathrm{mg}, 0.75 \mathrm{mmol})$. The solution was stirred at $60^{\circ} \mathrm{C}$ for $8 \mathrm{~h}$. Then the solution was diluted with water and washed with ethyl acetate $(2 \times 10 \mathrm{~mL})$. The collected organic layer was dried over $\mathrm{Na}_{2} \mathrm{SO}_{4}$ followed by filtration and evaporation in vacuo to furnish crude compound 18, which was then purified by column chromatography using $\left(\mathrm{SiO}_{2}\right.$, hexane: EtOAc 1:1) to afford pure

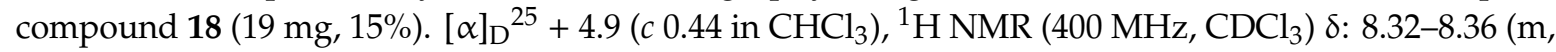
1H, ArH), 8.12-8.10 (m, 1H, ArH), 7.56-7.52 (m, 3H, ArH), 7.44-7.41 (m, 2H, ArH), 7.36-7.26 (m, 3H, ArH), $6.95(\mathrm{t}, 1 \mathrm{H}, J 8.0 \mathrm{~Hz}, \mathrm{ArH}), 6.52(\mathrm{t}, 1 \mathrm{H}, J 5.6 \mathrm{~Hz}, \mathrm{NH}), 5.60(\mathrm{~s}, 1 \mathrm{H}, \mathrm{CHPh}), 5.48(\mathrm{t}, 1 \mathrm{H}, J 10.0 \mathrm{~Hz}$, H-2), 4.39 (d, 1H, J 2.8 Hz, H-4), 4.31 (dd, 1H, J 12.5, 1.5 Hz, H-6a), 4.08 (dd, 1H, J 12.5, 1.6 Hz, H-6b), 3.97-3.92 (m, 1H, $\left.\mathrm{CH}_{2} \mathrm{NH}\right), 3.75-3.62\left(\mathrm{~m}, 2 \mathrm{H}, \mathrm{H}-1, \mathrm{CH}_{2} \mathrm{NH}\right), 3.52(\mathrm{~d}, 1 \mathrm{H}, J 1.0 \mathrm{~Hz} \mathrm{H}-5), 3.41(\mathrm{dd}, 1 \mathrm{H}, J$ 10.3, 2.3 Hz, H-3), 2.21 (s, 3H, $\left.\mathrm{CH}_{3}\right) .{ }^{13} \mathrm{C} \mathrm{NMR}\left(100 \mathrm{MHz}, \mathrm{CDCl}_{3}\right) \delta: 170.1,169.0,137.1,132.0,129.2$, 128.4, 128.3, 126.9, 126.1, 125.8, 125.70, 125.67, 125.65, 120.82, 120.77, 108.7, 108.5, 101.2, 76.1, 70.1, 69.4, 66.8, 62.5, 41.1, 40.0. HRMS calcd for $\mathrm{C}_{27} \mathrm{H}_{25} \mathrm{FN}_{4} \mathrm{O}_{6} \mathrm{Na}(\mathrm{M}+\mathrm{Na})^{+}: 543.1656$, found: 543.1658.

1-(4-Fluoro-naphth-1-amido)-2,6-anhydro-4-[4-(3,4,5-trifluorophenyl)-1H-1,2,3-triazol-1-yl]-1,4dideoxy-D-glycero-L-manno-heptitol 19: 
A solution of compound $18(19 \mathrm{mg}, 0.036 \mathrm{mmol})$ in $90 \%$ aq $\mathrm{AcOH}(10 \mathrm{~mL})$ was stirred at $90{ }^{0} \mathrm{C}$ for $3 \mathrm{~h}$. The solvents were evaporated and co-evaporated with toluene to remove residual AcOH. The residue was dissolved in $\mathrm{MeOH}(10 \mathrm{~mL})$, to which $\mathrm{NaOMe}$ in $\mathrm{MeOH}(0.5 \mathrm{M}, 1 \mathrm{~mL})$ was added and the solution was stirred at room temperature for $5 \mathrm{~h}$. The solution was then neutralized by DOWEX $50 \mathrm{~W} \mathrm{H}^{+}$resin, filtered, and evaporated. The residue $(18 \mathrm{mg}, 0.046 \mathrm{mmol})$ was dissolved in DMF $(10 \mathrm{~mL})$, followed by the successive addition of 3,4,5-trifluorophenyl acetylene ( $21 \mathrm{mg}, 0.138 \mathrm{mmol})$ and $\mathrm{CuI}(8 \mathrm{mg}, 0.1 \mathrm{mmol})$. After $5 \mathrm{~min}, \mathrm{Et}_{3} \mathrm{~N}(6.3 \mu \mathrm{L}, 0.046 \mathrm{mmol})$ was added and the mixture was stirred at room temperature for $48 \mathrm{~h}$. The solvent was evaporated in vacuo to furnish crude 18 , which was purified by column chromatography $\left(\mathrm{SiO}_{2}\right.$, hexane: EtOAc 1:12) to afford pure 19 (10.6 mg, $\left.42 \%\right)$. $[\alpha]_{\mathrm{D}}{ }^{25}+2.5(c 1.1$ in $\mathrm{MeOH}),{ }^{1} \mathrm{H}$ NMR $\left(400 \mathrm{MHz}, \mathrm{CD}_{3} \mathrm{OD}\right) \delta: 8.51$ (s, 1H, triazole H), 8.33-8.31 (m, 1H, ArH), 8.16-8.14 (m, 1H, ArH), 7.71-7.62 (m, 5H, ArH), 7.28 (t, 1H, J 8.0 Hz, ArH), 4.86 (d, 1H, J $3.2 \mathrm{~Hz}, \mathrm{H}-1), 4.30$ (dd, 1H, J 10.4, 9.0 Hz, H-2), 4.18 (dd, 1H, J 11.7, 1.7 Hz, CH $\mathrm{CHH}^{\mathrm{N}}, 4.12(\mathrm{~d}, 1 \mathrm{H}, J 3.2$ $\mathrm{Hz}, \mathrm{H}-4)$, 3.84-3.77 (m, 2H, H-5, H-6a), 3.72-3.62 (m, 3H, H-6b, $\left.\mathrm{CH}_{2} \mathrm{NH}, \mathrm{H}-1\right) .{ }^{13} \mathrm{C}$ NMR (100 MHz, $\left.\mathrm{CD}_{3} \mathrm{OD}\right) \delta:$ 172.1, 133.30, 133.25, 132.13, 132.09, 129.1, 128.0, 127.1, 126.7, 125.0, 124.9, 122.9, 121.5, 121.4, $110.9,110.7,109.7,109.5,81.2,80.7,70.1,69.2,67.2,62.9,42.5$. HRMS calcd for $\mathrm{C}_{26} \mathrm{H}_{23} \mathrm{~F}_{4} \mathrm{~N}_{4} \mathrm{O}_{5}(\mathrm{M}+\mathrm{H})^{+}$: 547.1605, found: 547.1614 .

Fluorescence polarization experiments:

Fluorescence polarization experiments were carried out either with a POLARStar plate reader and FLUOstar Galaxy software or with a PheraStarFS plate reader and PHERAstar Mars version 2.10 R3 software (BMG, Offenburg, Germany). The dissociation constant $(\mathrm{Kd})$ values were determined in PBS as described earlier [12,13]. Specific conditions for galectin-1, 3, 4N, 4C, 7, 8N, 9N, and 9C were kept as reported [32,33]. Average Kd values and SEMs were calculated from 2-8 single-triple point measurements showing between $30 \%$ and $70 \%$ inhibition.

Co-crystallization of galectin-3 C-terminal domain with compounds 14 and 19:

Galectin-3C [34] (C-terminal domain) solution $(12 \mu \mathrm{L}, 20 \mathrm{mg} / \mathrm{mL}$ in $10 \mathrm{mM}$ sodium phosphate buffer $\mathrm{pH} 7.5,100 \mathrm{mM} \mathrm{NaCl}$ and $10 \mathrm{mM} \beta$-mercaptoethanol) was mixed with either compound 14 or $19(1.2 \mu \mathrm{L}, 50 \mathrm{mM}$ in 100\% DMSO) and incubated on ice for $30 \mathrm{~min}$. Crystallization drops of $2+2$ $\mu \mathrm{L}$ were set up over $1 \mathrm{~mL}$ reservoir solution (30\% PEG 4000, $0.1 \mathrm{M}$ Tris/ $\mathrm{HCl}$ pH 7.5, $0.1 \mathrm{M} \mathrm{MgCl}, 0.4$ M NaSCN, $7.9 \mathrm{mM} \beta$-mercaptoethanol). Immediately after setup, the drops were seeded by adding $0.25 \mu \mathrm{L}$ of crystals of apo-galectin-3C that had been crushed using Seed Beads (Hampton Research) in a stabilizing solution (reservoir solution). Co-crystals of compound 14 measuring $0.03 \times 0.05 \times$ $0.05 \mathrm{~mm}$ and compound 19 measuring $0.1 \times 0.15 \times 0.15 \mathrm{~mm}$ were flash-frozen in cryo solution $(15 \%$ glycerol, 25.5 w/v \% PEG 4000, 250 mM NaSCN, 85 mM Tris/HCl pH 7.5, 85 mM MgCl , 2.5 mM 14 or $0.5 \mathrm{mM} 19)$.

Data collection and structure solution of galectin-3C in complex with $\mathbf{1 3}$ and 18:

Data to $1.5 \AA$ for compound 14 were collected at $100 \mathrm{~K}$ at station 1911-3 of MAX-lab, Lund, Sweden $(\lambda=1.0000 \AA)$, equipped with a marMosaic $225 \mathrm{~mm}$ CCD detector. Data to $1.4 \AA$ for compound 19 were collected at station I911-2 of the same synchrotron $(\lambda=1.0384 \AA)$, equipped with a marCCD $165 \mathrm{~mm}$ detector. Data for both structures were integrated using XDS and scaled using XSCALE [35]. The structures were refined using Refmac5 [36] with PDB entry 3ZSL [31] as starting model, first by rigid-body refinement. $5 \%$ of the total reflections were randomly set aside for cross validation. The graphic software Coot [37] has been used for model building and Monomer Library Sketcher software [38] for generation of restraints for the ligands $\mathbf{1 4}$ and 19. The models were refined to a resolution of $1.5 \AA / 1.4 \AA$ with anisotropic B-factors. Water molecules were added to positive difference density peaks more than $5 \sigma$ above the mean and present in the $2 \mathrm{~m}|\mathrm{Fo}|-\mathrm{d}|\mathrm{Fc}| \mathrm{map}$ at $1 \sigma$ level. Refinement statistics are listed in Table S1. Molecular images were generated using PyMOL v1.7 (Schrödinger LLC, New York, NY, USA). 
Supplementary Materials: The following are available online, Copies of ${ }^{1} \mathrm{H}$ and ${ }^{13} \mathrm{C}$ nmr spectra, Table S1: Data processing and refinement statistics for the X-ray crystal structures of $\mathbf{1 4}$ and 19 in complex with galectin-3.

Author Contributions: Conceptualization, H.L. and U.J.N.; Data curation, A.D., S.M., K.P., M.H. and F.R.Z.; Formal analysis, A.D., S.M., K.P., M.H. and D.T.L.; Funding acquisition, H.L. and U.J.N.; Project administration, U.J.N.; Supervision, F.R.Z. and U.J.N.; Writing—original draft, A.D., S.M., M.H. and U.J.N.; Writing一review \& editing, A.D., S.M., K.P., M.H., D.T.L., F.R.Z. and U.J.N.

Funding: This research was funded by The Swedish Research Council (Grants No. 621-2009-5326 and 621-2012-2978), the European Community's Seventh Framework Program [FP7-2007-2013] under grant agreement $\mathrm{n}^{\circ}$ HEALTH-F2-2011-256986-project acronym PANACREAS), the Royal Physiographic Society, Lund, Sweden, and Galecto Biotech AB, Sweden.

Acknowledgments: We thank Barbro Kahl-Knutson for excellent assistance with determining affinities by fluorescence polarization and Sofia Essén for excellent assistance with hrms and analytical hplc experiments.

Conflicts of Interest: H.L. and U.J.N. are shareholders in and F.Z. an employee of Galecto Biotech AB, Sweden.

\section{References}

1. Liu, F.-T.; Rabinovich, G.A. Galectins as modulators of tumour progression. Nat. Rev. Cancer 2005, 5, $29-41$. [CrossRef] [PubMed]

2. Liu, F.-T.; Rabinovich, G.A. Galectins: Regulators of acute and chronic inflammation. Ann. N. Y. Acad. Sci. 2010, 1183, 158-182. [CrossRef] [PubMed]

3. Nabi, I.R.; Shankar, J.; Dennis, J.W. The galectin lattice at a glance. J. Cell. Sci 2015, 128, 2213-2219. [CrossRef]

4. Johannes, L.; Jacob, R.; Leffler, H. Galectins at a glance. J. Cell. Sci 2018, 131, jcs208884. [CrossRef]

5. Thiemann, S.; Baum, L.G. Galectins and Immune Responses-Just How Do They Do Those Things They Do? Annu. Rev. Immunol. 2016, 34, 243-264. [CrossRef]

6. Li, Y.-S.; Li, X.-T.; Yu, L.-G.; Wang, L.; Shi, Z.-Y.; Guo, X-L. Guo Roles of galectin-3 in metabolic disorders and tumor cell metabolism. Int. J. Biol. Macromol. 2019, in press. [CrossRef]

7. Tejler, J.; Leffler, H.; Nilsson, U.J. Synthesis of O-galactosyl aldoximes as potent LacNAc-mimetic galectin-3 inhibitors. Bioorg. Med. Chem. Lett. 2005, 15, 2343-2345. [CrossRef]

8. Tejler, J.; Salameh, B.; Leffler, H.; Nilsson, U.J. Fragment-based development of triazole-substituted O-galactosyl aldoximes with fragment-induced affinity and selectivity for galectin-3. Org. Biomol. Chem. 2009, 7, 3982-3990. [CrossRef]

9. Dahlqvist, A.; Leffler, H.; Nilsson, U.J. C1-Galactopyranosyl Heterocycle Structure Guides Selectivity: Triazoles Prefer Galectin-1 and Oxazoles Prefer Galectin-3. ACS Omega 2019, 4, 7047-7053. [CrossRef]

10. Uchiyama, T.; Woltering, T.J.; Wong, W.; Lin, C.C.; Kajimoto, T.; Takebayashi, M.; Weitz-Schmidt, G.; Asakura, T.; Noda, M.; Wong, C.-H. Design and synthesis of C-linked fucosides as inhibitors of E-selectin. Bioorg. Med. Chem. Lett. 1996, 4, 1149-1165. [CrossRef]

11. Coxon, B.; Fletcher, H.G. The Structure of 2,3,4,6-Tetra-O-acetyl- $\beta$-D-galactopyranosyl Cyanide and Some Derivatives Therefrom. Synthesis of 1-Deoxy-D- galacto-heptulose. J. Am. Chem. Soc. 1964, 86, 922-926. [CrossRef]

12. Sörme, P.; Kahl-Knutsson, B.; Huflejt, M.; Nilsson, U.J.; Leffler, H. Fluorescence polarization as an analytical tool to evaluate galectin-ligand interactions. Anal. Biochem. 2004, 334, 36-47. [CrossRef]

13. Delaine, T.; Collins, P.; Mackinnon, A.; Sharma, G.; Stegmayr, J.; Rajput, V.K.; Mandal, S.; Cumpstey, I.; Larumbe, A.; Salameh, B.A.; et al. Galectin-3-Binding Glycomimetics that Strongly Reduce Bleomycin-Induced Lung Fibrosis and Modulate Intracellular Glycan Recognition. ChemBioChem 2016, 17, 1759-1770. [CrossRef] [PubMed]

14. Cumpstey, I.; Carlsson, S.; Leffler, H.; Nilsson, U. Synthesis of a phenyl thio-beta-D-galactopyranoside library from 1,5-difluoro-2,4-dinitrobenzene: Discovery of effcient and selective monosaccharide inhibitors of galectin-7. Org. Biomol. Chem. 2005, 3, 1922-1932. [CrossRef]

15. Rajput, V.K.; Mackinnon, A.; Mandal, S.; Collins, P.; Blanchard, H.; Leffler, H.; Sethi, T.; Schambye, H.; Mukhopadhyay, B.; Nilsson, U.J. A Selective Galactose-Coumarin-Derived Galectin-3 Inhibitor Demonstrates Involvement of Galectin-3-glycan Interactions in a Pulmonary Fibrosis Model. J. Med. Chem. 2016, 59, 8141-8147. [CrossRef] [PubMed]

16. Nilsson, U.J.; Leffler, H.; Mukhopadhyay, B.; Rajput, V. Galectoside inhibitors of galectins. U.S. Patent US9353141B2, 31 May 2016. 
17. Peterson, K.; Kumar, R.; Verma, P.; Verma, P.R.; Zetterberg, F.; Akke, M. Systematic Tuning of Fluoro-galectin-3 Interactions Provides Thiodigalactoside Derivatives with Single-Digit nM Affinity and High Selectivity. J. Med. Chem. 2018, 61, 1164-1175. [CrossRef] [PubMed]

18. Zetterberg, F.R.; Peterson, K.; Johnsson, R.E.; Brimert, T.; Håkansson, M.; Logan, D.T.; Leffler, H.; Nilsson, U.J. Monosaccharide Derivatives with Low-Nanomolar Lectin Affinity and High Selectivity Based on Combined Fluorine-Amide, Phenyl-Arginine, Sulfur- $\pi$, and Halogen Bond Interactions. ChemMedChem 2018, 27, 133-137. [CrossRef]

19. Cui, S.-L.; Lin, X.-F.; Wang, Y.-G. Novel and Efficient Synthesis of Iminocoumarins via Copper-Catalyzed Multicomponent Reaction. Org. Lett. 2006, 8, 4517-4520. [CrossRef]

20. Peterson, K.; Weymouth-Wilson, A.; Nilsson, U.J. Aryl Sulfonates in Inversions at Secondary Carbohydrate Hydroxyl Groups: A New and Improved Route Toward 3-Azido-3-deoxy- $\beta$-d-galactopyranosides. J. Carbohydr. Chem. 2015, 1-10. [CrossRef]

21. Tornoe, C.W.; Christensen, C.; Meldal, M. Peptidotriazoles on solid phase: [1,2,3]-triazoles by regiospecific copper(I)-catalyzed 1,3-dipolar cycloadditions of terminal alkynes to azides. J. Org. Chem. 2002, 67, 3057-3064. [CrossRef]

22. Rostovtsev, V.V.; Green, L.G.; Fokin, V.V.; Sharpless, K.B. A stepwise Huisgen cycloaddition process: Copper(I)-catalyzed regioselective "ligation" of azides and terminal alkynes. Angew. Chem. Int. Ed. Engl. 2002, 41, 2596-2599. [CrossRef]

23. Öberg, C.-T.; Blanchard, H.; Leffler, H.; Nilsson, U.J. Protein subtype-targeting through ligand epimerization: Talose-selectivity of galectin-4 and galectin-8. Bioorg. Med. Chem. Lett. 2008, 18, 3691-3694. [CrossRef] [PubMed]

24. Mandal, S.; Rajput, V.K.; Sundin, A.P.; Leffler, H.; Mukhopadhyay, B.; Nilsson, U.J. Galactose-amidine derivatives as selective antagonists of galectin-9. Can. J. Chem. 2016, 94, 936-939. [CrossRef]

25. Seetharaman, J.; Kanigsberg, A.; Slaaby, R.; Leffler, H.; Barondes, S.H.; Rini, J.M. X-ray crystal structure of the human galectin-3 carbohydrate recognition domain at 2.1-A resolution. J. Biol. Chem. 1998, 273, 13047-13052. [CrossRef] [PubMed]

26. Kumar, R.; Ignjatović, M.M.; Peterson, K.; Olsson, M.; Leffler, H.; Ryde, U.; Nilsson, U.J.; Logan, D.T. Structure and Energetics of Ligand-Fluorine Interactions with Galectin-3 Backbone and Side-Chain Amides: Insight into Solvation Effects and Multipolar Interactions. ChemMedChem 2019, 73, 4345-4349. [CrossRef]

27. Zürcher, M.; Diederich, F. Structure-based drug design: Exploring the proper filling of apolar pockets at enzyme active sites. J. Org. Chem. 2008, 73, 4345-4361. [CrossRef]

28. Sörme, P.; Arnoux, P.; Kahl-Knutsson, B.; Leffler, H.; Rini, J.M.; Nilsson, U.J. Structural and thermodynamic studies on cation-Pi interactions in lectin-ligand complexes: High-affinity galectin-3 inhibitors through fine-tuning of an arginine-arene interaction. J. Am. Chem. Soc. 2005, 127, 1737-1743. [CrossRef]

29. Noresson, A.L.; Aurelius, O.; Oberg, C.T.; Engström, O.; Sundin, A.P.; Håkansson, M.; Stenström, O.; Akke, M.; Logan, D.T.; Leffler, H.; et al. Designing interactions by control of protein-ligand complex conformation: Tuning arginine-arene interaction geometry for enhanced electrostatic protein-ligand interactions. Chem. Sci. 2018, 9, 1014-1021. [CrossRef]

30. Kumar, R.; Peterson, K.; Misini Ignjatović, M.; Leffler, H.; Ryde, U.; Nilsson, U.J.; Logan, D.T. Substituted polyfluoroaryl interactions with an arginine side chain in galectin-3 are governed by steric-, desolvation and electronic conjugation effects. Org. Biomol. Chem. 2019, 17, 1081-1089. [CrossRef]

31. Saraboji, K.; Håkansson, M.; Genheden, S.; Diehl, C.; Qvist, J.; Weininger, U.; Nilsson, U.J.; Leffler, H.; Ryde, U.; Akke, M.; et al. The carbohydrate-binding site in galectin-3 is preorganized to recognize a sugarlike framework of oxygens: Ultra-high-resolution structures and water dynamics. Biochemistry 2012, 51, 296-306. [CrossRef]

32. Öberg, C.T.; Carlsson, S.; Fillion, E.; Leffler, H.; Nilsson, U.J. Efficient and Expedient Two-Step Pyranose-Retaining Fluorescein Conjugation of Complex Reducing Oligosaccharides: Galectin Oligosaccharide Specificity Studies in a Fluorescence Polarization Assay. Bioconj. Chem. 2003, 14, 1289-1297. [CrossRef] [PubMed]

33. Pal, K.B.; Mahanti, M.; Leffelr, H.; Nilsson, U.J. A Galactoside-Binding Protein Tricked into Binding Unnatural Pyranose Derivatives: 3-Deoxy-3-Methyl-Gulosides Selectively Inhibit Galectin-1. Int. J. Mol. Sci. 2019, 20, 3786. [CrossRef] [PubMed] 
34. Diehl, C.; Engström, O.; Delaine, T.; Håkansson, M.; Genheden, S.; Modig, K.; Leffler, H.; Ryde, U.; Nilsson, U.J.; Akke, M. Protein Flexibility and Conformational Entropy in Ligand Design Targeting the Carbohydrate Recognition Domain of Galectin-3. J. Am. Chem. Soc. 2010, 132, 14577-14589. [CrossRef] [PubMed]

35. Kabsch, W. XDS. Acta Cryst. Sec. D 2010, D66, 125-132. [CrossRef]

36. Afonine, P.V.; Grosse-Kunstleve, R.W.; Echols, N.; Headd, J.J.; Moriarty, N.W.; Mustyakimov, M.; Terwilliger, T.C.; Urzhumtsev, A.; Zwart, P.H.; Adams, P.D. Towards automated crystallographic structure refinement with phenix.refine. Acta Cryst. Sec. D 2012, D68, 352-367. [CrossRef]

37. Emsley, P.; Cowtan, K. Coot: Model-building tools for molecular graphics. Acta Cryst. Sec. D 2004, 60, 2126-2132. [CrossRef]

38. Winn, M.D.; Ballard, C.C.; Cowtan, K.D.; Dodson, E.J.; Emsley, P.; Evans, P.R.; Keegan, R.M.; Krissinel, E.B.; Leslie, A.G.W.; McCoy, A.; et al. Overview of the CCP4 suite and current developments. Acta Cryst. Sec. D 2011, 67, 235-242. [CrossRef]

Sample Availability: Samples of the compounds are not available from the authors.

(C) 2019 by the authors. Licensee MDPI, Basel, Switzerland. This article is an open access article distributed under the terms and conditions of the Creative Commons Attribution (CC BY) license (http://creativecommons.org/licenses/by/4.0/). 